\title{
$\beta 1$ Integrins Control the Formation of Cell Chains in the Adult Rostral Migratory Stream
}

\author{
Richard Belvindrah, ${ }^{1}$ Sabine Hankel, ${ }^{1}$ John Walker, ${ }^{2}$ Bruce L. Patton, ${ }^{3}$ and Ulrich Müller ${ }^{1}$ \\ ${ }^{1}$ The Scripps Research Institute, Department of Cell Biology, Institute for Childhood and Neglected Disease, La Jolla, California 92037, ${ }^{2}$ Genomic Institute of \\ the Novartis Research Foundation, San Diego, California 92121, and ${ }^{3}$ Oregon Health and Science University, Portland, Oregon 97239
}

The subventricular zone (SVZ) of the lateral ventricle is the major site of neurogenesis in the adult brain. Neuroblasts that are born in the SVZ migrate as chains along the rostral migratory stream (RMS) to the olfactory bulb. Little is known about the mechanisms that control interactions between neuroblasts during their migration. Here we show that migrating neuroblasts express $\beta 1$ integrins and that the integrin ligand laminin is localized to cell chains. Using genetically modified mice and time-lapse video recordings of SVZ explants, we demonstrate that $\beta 1$ integrins and laminin promote the formation of cell chains. Laminin also induces the aggregation of purified neuroblasts. We conclude that the formation of cell chains in the RMS is controlled in part by $\beta 1$ integrins via binding to laminin. In addition, we provide evidence that $\beta 1$ class integrins are required for the maintenance of the glial tubes and that defects in the glial tubes lead to the ectopic migration of neuroblasts into the surrounding tissue.

Key words: $\beta 1$ integrins; SVZ; RMS; migration; laminin; CNS

\section{Introduction}

Neurons are generated in the adult mammalian brain throughout life from neural stem cells that are localized in specialized niches (Alvarez-Buylla and Lim, 2004; Kempermann et al., 2004). The major site of neurogenesis in the adult mammalian brain is the subventricular zone (SVZ) of the lateral ventricle (Alvarez-Buylla and Lim, 2004; Lledo et al., 2006). Slow dividing stem cells (type $\mathrm{B}$ cells) in the SVZ give first rise to transit amplifying cells (type C cells), which generate fast dividing neuroblasts (type A cells) that migrate tangentially within glial tubes along the rostral migratory stream (RMS) to the olfactory bulb (OB). In the OB, the cells switch to a mode of radial migration and differentiate into interneurons of the granular and periglomerular layers (Luskin, 1993; Lois and Alvarez-Buylla, 1994).

Several secreted signaling molecules control the directional migration of neuroblasts in the RMS to ensure that appropriate numbers of cells arrive, in a timely manner, in appropriate cell layers of the $\mathrm{OB}$ to replace preexisting interneurons. These include diffusible chemoattractants such as netrin-1, prokineticin-2, and glial cell line-derived neurotrophic factor, as well as chemorepellents such as slit1/2 (Wu et al., 1999; Murase

Received July 14, 2006; revised Jan. 26, 2007; accepted Jan. 29, 2007.

This work was funded by National Institutes of Health Grants R01-NS046456 and U01-MH078833 (U.M.). We thank the following: G. Rougon, Harold Cremer (both at Université de la Mediterranée Aix-Marseille 2, Marseille, France) and L. Sorokin (University of Uppsala, Uppsala, Sweden) for antibodies; Dr. K. Hodivala-Dilke (Cancer Research UK, London, UK) and Dr. D. Sheppard (University of California, San Francisco, San Francisco, CA) for tissue from Itgb5-null mice; Dr. K. S. Spencer (The Scripps Research Institute, La Jolla, CA) for help for live imaging; Dr. M. Wood (The Scripps Research Institute) for help with electron microscopy; the flow cytometry core facility of The Scripps Research Institute for FACS; Susan Sutton (Genomics Institute of the Novartis Research Foundation, San Diego, (A) for microarray studies; and members of the laboratory for critical discussion.

Correspondence should be addressed to Ulrich Müller, Scripps Research Institute, 10550 North Torrey Pines Road, La Jolla, CA 92073. E-mail: umueller@scripps.edu.

DOI:10.1523/JNEUROSCI.2991-06.2007

Copyright $\odot 2007$ Society for Neuroscience $\quad$ 0270-6474/07/272704-14\$15.00/0 and Horwitz, 2002; Nguyen-Ba-Charvet et al., 2004; Ng et al., 2005; Paratcha et al., 2006). The CSF flows parallel to the direction of migration, and its flow is required for the formation of gradients of guidance molecules in the RMS (Sawamoto et al., 2006), providing a potential mechanism controlling directional neuroblast migration. In addition, receptor tyrosine kinases of the Eph and ErbB families and their respective ephrin and neuregulin ligands have been implicated in controlling chain migration in the RMS (Conover et al., 2000; Anton et al., 2004; Ghashghaei et al., 2006). Subsequent to arrival in the OB, signaling molecules such as reelin, tenascin $\mathrm{R}$, and prokineticin-2 induce detachment of neuroblasts from cell chains (Hack et al., 2002; Saghatelyan et al., 2004; $\mathrm{Ng}$ et al., 2005), controlling the switch from tangential to radial migration.

Ultimately, secreted signaling molecules must control the activity of cell surface receptors that regulate interactions of neuroblasts with each other and with cues in their environment. The adjustment of these interactions is essential for directional movement of cell chains at defined speed, dispersal of cell chains on arrival within the $\mathrm{OB}$, and migrational arrest of the cells in their final target areas. The neural cell adhesion molecule (NCAM) is expressed on type A neuroblasts and, although not essential for chain formation, controls interactions of neuroblasts with the stationary environment through which the cells migrate. Defects in this process affect the motility of cell chains and the size of the OB (Tomasiewicz et al., 1993; Cremer et al., 1994; Ono et al., 1994; Hu et al., 1996; Chazal et al., 2000). It has also been proposed that neuroblast motility is controlled by integrins. Integrins are heterodimeric cell surface molecules consisting of one $\alpha$ and one $\beta$ subunit that bind to extracellular matrix (ECM) components and counter receptors on adjacent cells. In vertebrates, genes for $18 \alpha$ and $8 \beta$ subunits have been identified. These subunits assemble into 24 different receptors that fall into subfami- 
lies such as the $\beta 1$ integrins, which form by heterodimerization of the $\beta 1$ subunit with $12 \alpha$ subunits (Hynes, 2002). $\beta 1$ integrins have been reported to control the motility of neuroblast, but the findings have been conflicting. One study has reported that $\beta 1$ integrins are expressed in the RMS until postnatal day 10 (P10) and that antibodies to $\beta 1$ slow down migration before but not after P10 (Murase and Horwitz, 2002). A second study has provided evidence that the integrin $\alpha 6 \beta 1$ is expressed even in the adult RMS and that injection of $\beta 1$ antibodies disrupts the adult RMS (Emsley and Hagg, 2003). In both studies, it has remained unclear whether the antibodies affected the migration of neuroblasts directly or indirectly through effects on other cells or other aspects of cell behavior such as proliferation and differentiation.

Despite the identification of receptors and signaling molecules that control the migration of neuroblasts, little is known about the mechanisms regulating the interactions between neuroblasts during chain migration. Our findings now reveal an unexpected function for $\beta 1$ integrins in this process. We show here that neuroblasts express integrins containing the $\beta 1$ and $\beta 5$ subunits. Using genetic and cell biological approaches, we demonstrate that $\beta 5$ integrins are dispensable for chain migration, whereas $\beta 1$ integrins promote cell-cell interactions that link neuroblasts into chains. The $\beta 1$ integrin ligand laminin is recruited to the cell surface of migrating neuroblasts and induces chain formation in SVZ explants and the aggregation of purified neuroblasts. We conclude that $\beta 1$ integrins and their laminin ligands promote the formation of cell chains in the adult RMS. We also provide evidence that $\beta 1$ class integrins are required for maintaining the integrity of the glial tubes.

\section{Materials and Methods}

Animals. Itgb1-CNSko mice were generated by crossing Itgb $1^{\text {flox/flox }}$ mice with Itgb fllox/+ ${ }^{\text {nestin-Cre }}{ }^{+/-}$mice (Graus-Porta et al., 2001). Itgb5-null mice, and mice carrying mutations in the Lama2 (laminin alpha 2) and Lama4 (laminin alpha 4) genes have been described (Sunada et al., 1994; Xu et al., 1994; Patton et al., 2001). Mutants and control littermates were used for all experiments.

Fluorescence-activated cell sorting. The SVZ and the distal part of the RMS at the level of the OB were dissected in cold HBSS without $\mathrm{Ca}^{2+}$ and $\mathrm{Mg}^{2+}$ (Invitrogen, Carlsbad, CA) from four wild-type C57BL/6 mice at P60. Cells were dissociated for $6 \mathrm{~min}$ at $37^{\circ} \mathrm{C}$ with $5 \mathrm{mg} / \mathrm{ml}$ trypsin (Worthington, Lakewood, NJ) and 0.1\% Dnase I (Worthington), dissociated mechanically in sorting buffer (HBSS without $\mathrm{Ca}{ }^{2+}$ and $\mathrm{Mg}^{2+}$ without phenol red, 1 mM EDTA, 25 mM HEPES, pH 7.0, and 1\% FBS), and filtered through a $40 \mu \mathrm{m}$ nylon cell strainer (BD Biosciences, San Jose, CA). Cells were stained with an anti-polysialic acid (PSA) antibody for $15 \mathrm{~min}$ at $4^{\circ} \mathrm{C}$ in sorting buffer, rinsed, and then stained with an anti-mouse IgM FITC-conjugated antibody (Jackson ImmunoResearch, West Grove, PA) for $15 \mathrm{~min}$ at $4^{\circ} \mathrm{C}$. PSA-positive cells were sorted directly into the lysis buffer using a fluorescence-activated cell sorting (FACS) Vantage DiVa (BD Biosciences) and processed for RNA purification. Unstained cells and cells stained with the secondary antibody only were used as negative controls. Two independent experiments were performed for both regions (SVZ and RMS) to collect two samples of 30,000 cells from the SVZ and two samples of 100,000 cells from the RMS.

Gene expression sample and microarray processing. Total RNA was examined on an Agilent (Palo Alto, CA) Bioanalyzer, and the $28 \mathrm{~S} / 18 \mathrm{~S}$ ratio exceeded 2.0 for all samples. RNA quantity was estimated from this analysis. Total RNA (20 ng) was reverse transcribed and amplified with three rounds of amplification as described previously (Scherer et al., 2003). The in vitro transcription kit used for the final amplification was from Enzo Diagnostics (Farmingdale, NY). The same individual processed all reactions and arrays at the same time. Fragmented and labeled cRNA was hybridized to custom Affymetrix (Santa Clara, CA) arrays as described below. Arrays were washed using a custom Genomics Institute of the Novartis Research Foundation microarray washer for the low-stringency washes and otherwise used standard Affymetrix protocols. Arrays were scanned with a G2500A (Affymetrix) scanner. MAS5.0 (Affymetrix) quality control measures of "Average Background" and "Percentage Present" were examined from .CHP and .RPT files produced by default setting of the MAS5.0 algorithm. All arrays passed the criteria of no more than two SDs from the mean for both of these measures simultaneously.

Measurement data and specifications. Probe values were condensed from probe sets using MAS5 software (Affymetrix). Arrays were globally scaled to an average intensity value of 200. Detectable expression was defined as at least two times above the average intensity (across all arrays) for the average value in at least one experimental group. Significant fold change values were defined as being at least a fold change of 1.5 and, when the coefficient of variation, across replicates, was less than a value of 0.6 in both experimental groups.

Array Design. A custom mouse microarray, GNF1M, (Affymetrix) was used for these experiments. A description of the contents of this array has been described previously (Su et al., 2004).

Quantitative reverse transcription-PCR analysis. Three brains from 2-month-old C57BL/6 mice were dissected, and coronal sections ( $\sim 500$ $\mu \mathrm{m}$ thick) were prepared with a scalpel. The SVZ and granule cell layer from the OB were dissected, total RNA was isolated using RNeasy kit (Qiagen, Valencia, CA), and RNA $(1 \mu \mathrm{g})$ was retrotranscribed into cDNA using oligo-dT with Superscript Strand II cDNA synthesis kit (Invitrogen). Real-time quantitative PCR was performed on Chromo4 (MJ Research via Bio-Rad, Hercules, CA) using SYBR green chemistry (Applied Biosystems, Foster City, CA) as described previously (Teyssier et al., 2005). Primers were as follows: glyceraldehyde-3-phosphate dehydrogenase (GAPDH) forward, 5'-TCAACGGGAAGCCCATCA-3'; GAPDH reverse, 5'-CTCGTGGTTCACACCCATCA-3'; Itgb1 forward, 5'-TGTTGGTCAGCAACGCATATC-3'; Itgbl reverse, 5'-TCCCATCTCCAGCAAAGTGAA-3'; Itgb3 forward, 5'-CAACGTCCTCCAGCTCATTGT-3'; Itgb3 reverse, 5' -TTCCGGCAGGTCACGTACTT3'; Itgb5 forward, 5'-GCTGCTGTCTGCAAGGAGAAG-3'; Itgb5 reverse, 5'-CACCCAGTTTTCCATCCAGTG-3'; Itgal forward, 5'CGTCCTAGATGGCTCCAACAG-3'; Itgal reverse, 5' -CTATTTTGTTTGCTGCCACCA-3'; Itga 2 forward, 5'-GCTTGATGCGGACGGACATT-3'; Itga2 reverse, 5'-CACACGCAGATCCAAAGGGT-3'; Itga3 forward, 5'-CTACTCCCTGAGCGGGAAGAT-3'; Itga3 reverse, 5' GTACAAAGCGCAGGGTCCAAC-3'; Itga6 forward, 5' -GAATTGACCTCCGCCAGAAGT-3'; Itga6 reverse, 5' -ATACTTTGGCTCGGAACCTTG-3'; Itga7 forward, 5'-CGATGGACGCTTGGTCTGTG-3'; and Itga7 reverse, 5'-CTGATGCCTGAGGTCATCCA-3'. Relative mRNA levels for each integrin subunit was determined using the comparative threshold cycle method (Applied Biosystems) and have been normalized to GAPDH mRNA levels. Results are expressed as number of copies of mRNA relative to 1000 copies of GAPDH mRNA. The experiments have been performed three times in duplicate for each set of genes. Values are given as mean \pm SEM. A Student's $t$ test was performed.

Histology and immunohistochemistry. The analyses were performed with at least three mutant mice (Itgb1-CNSko, Itgb5-null, laminin $\alpha 2 / \alpha 4$ double mutants) and control littermates. LacZ and Nissl stainings were performed as described previously (Graus-Porta et al., 2001). For immunohistochemistry, mice were perfused with $4 \%$ paraformaldehyde in PBS. Brains were dissected, postfixed overnight at $4^{\circ} \mathrm{C}$ and embedded in $3.5 \%$ agarose and $8 \%$ sucrose. Sagittal vibratome sections $(50 \mu \mathrm{m})$ were prepared and stained as floating sections in 48 well plates. Sections were incubated with PBS containing 10\% goat serum (Invitrogen) (blocking buffer) for $1 \mathrm{~h}$ at room temperature (RT) and incubated with primary antibody in blocking buffer for $1 \mathrm{~h}$ at RT or overnight at $4^{\circ} \mathrm{C}$. For some antibodies, $0.5 \%$ Triton X-100 was included to permeabilize the cells. Sections were rinsed with blocking buffer and incubated for $1 \mathrm{~h}$ at RT with secondary antibodies coupled to fluorochromes (Invitrogen). Nuclei were counterstained for $10 \mathrm{~min}$ at RT with $4^{\prime}, 6^{\prime}$-diamidino-2phenylindole (DAPI) ( $1 \mu \mathrm{g} / \mathrm{ml}$; Sigma, St. Louis, MO). Sections were rinsed and mounted with ProLong Gold antifade mounting medium (Invitrogen). Stainings were analyzed with a confocal microscope (Fluoview-LSM; Olympus Optical, Melville, NY) or a deconvolution microscope (Deltavision; Applied Precision, Issaquah, Washington). The following antibodies were used: anti- $\beta 1$ integrins rabbit polyclonal (Graus- 
Porta et al., 2001), GFAP rabbit polyclonal (DakoCytomation, Glostrup, Denmark), PSANCAM mouse IgM (kindly provided by G. Rougon, Université de la Mediterranée AixMarseille 2, Marseille, France), bromodeoxyuridine (BrdU) mouse IgG (BD Biosciences), laminin rabbit polyclonal (kindly provided by L. Sorokin, University of Uppsala, Uppsala, Sweden), calretinin, polyclonal rabbit (Chemicon, Temecula, CA), caspase 3 polyclonal rabbit (Asp175; Cell Signaling Technology, Beverly, MA). Staining with mouse anti BrdU IgG was performed as described previously (Belvindrah et al., 2002). Mice were administered with BrdU $(10 \mathrm{mg} / \mathrm{ml}$ in PBS, 50 $\mathrm{mg} / \mathrm{kg}$ of body weight). Mice were analyzed either $1 \mathrm{~h}$ later (to study cell proliferation) or after 7 or $21 \mathrm{~d}$ after the single BrdU pulse (to study cell migration). To test cell proliferation, nuclei that stained positive for BrdU were counted in the SVZ, using a standardized counting area: BrdU-positive nuclei from three adjacent sections (at the same anatomical level on the side of the SVZ bordering the lateral ventricle) were counted from three Itgb1-CNSko mice and three control littermates. Staining with DAPI did not reveal any changes in cell density. To test cell migration, nuclei that stained positive for BrdU in the proximal and distal RMS, and the granule cell layer in the $\mathrm{OB}$ (noted as regions 1, 2, and 3 in Fig. 5a) were counted in a $3600 \mu \mathrm{m}^{2}$ square in three adjacent sections from three adult Itgb1-CNSKo and littermate controls for each experiment ( 7 and $21 \mathrm{~d}$ chase). All values are given as mean \pm SEM. A Student's $t$ test was performed.

$O B$ volume quantification. To estimate the OB volume, serial coronal sections were prepared with a Vibratome (Leica, Nussloch, Germany) after intracardiac perfusion with paraformaldehyde (PFA) and postfixation of brains overnight at $4^{\circ} \mathrm{C}$. A total of three Itgb1-CNSko mice and three control littermates were processed. Serial sections were stained with Nissl as described previously (Belvindrah et al., 2002). The surface of the OB was determined using MetaMorph Software (Molecular Devices, Palo Alto, CA). We therefore measured the $\mathrm{OB}$ area in each section $\left(A_{1}-A_{n}\right)$ and determined the final volume by summing up the surface area and multiplying it with the thickness of the sections $\left[\Sigma\left(\mathrm{A}_{1} \ldots A_{n}\right) \times 50 \mu \mathrm{m}\right.$; result expressed as cubic millimeters]. Values are given as mean \pm SEM. A Student's $t$ test was performed.

Electron microscopy. Mice were perfused with $2 \% \mathrm{PFA} / 2 \%$ glutaraldehyde in PBS and postfixed overnight at $4^{\circ} \mathrm{C}$. Brains were cut into $50-\mu \mathrm{m}$-thick sections. Sections were washed $30 \mathrm{~min}$ in $0.1 \mathrm{M} \mathrm{Na}$ cacodylate buffer, $\mathrm{pH} 7.3$, and postfixed for $1 \mathrm{~h}$ with $1 \% \mathrm{OsO}_{4}$ in $0.1 \mathrm{M} \mathrm{Na}$ cacodylate buffer. Sections are dehydrated with increasing concentration of ethanol (50, 70, 90, and $100 \%)$. Samples are incubated in propylene oxide and impregnated overnight in Epon/Araldite resin before polymerization at $60^{\circ} \mathrm{C}$. Thin sections were stained with lead citrate before observation in the electron microscope.

Matrigel time-lapse video microscopy. Matrigel experiments were performed as described previously (Wichterle et al., 1997). Briefly, P0-P4 mouse brains were dissected, coronal sections $(\sim 500 \mu \mathrm{m}$ thick) were prepared with a scalpel, and the SVZ was carefully dissected out from the wall of the anterior horn of the lateral ventricle and cut into pieces of

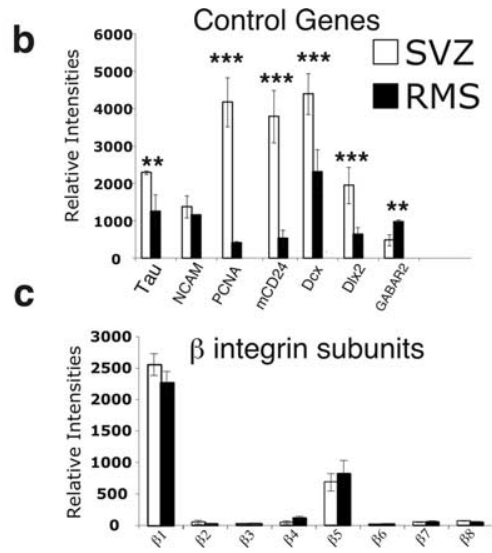

d

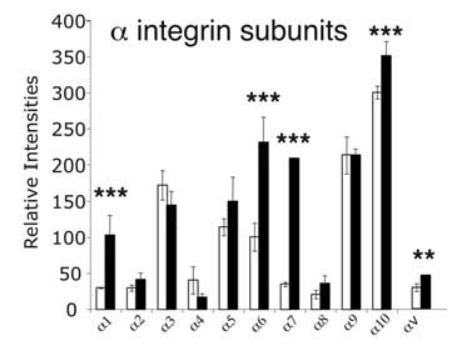

f

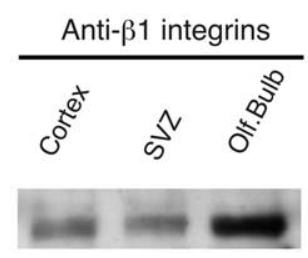

g

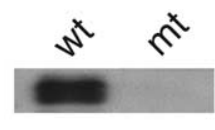

Figure 1. Analysis of the integrin expression pattern in PSA-NCAM-positive neuroblasts. $\boldsymbol{a}$, The SVZ was microdissected from adult wild-type mice, and the cells were dissociated and FACS sorted using antibodies to PSA-NCAM. The number of cells is plotted against the fluorescence intensity. The top shows a control without PSA-NCAM antibody. The PSA-NCAM-positive cell population is indicated by the boxed area. $\boldsymbol{b}-\boldsymbol{d}$, Fluorescence-labeled probes prepared from RNA samples from PSA-NCAM-positive cells from determined as described in Material and Methods. The samples were analyzed for the expression of marker genes $(\boldsymbol{b}), \beta$ integrin subunits (c), and $\alpha$ integrin subunits (d). The FACS-sorted cells expressed the appropriate markers for PSA-NCAM-positive levels of the $\alpha 1, \alpha 6$, and $\alpha 7$ subunits were higher in samples from the RMS than SVZ.e, Quantitative reverse transcription-PCR analysis. The mRNA expression levels of the different integrin subunits (expressed as copy number per 1000 copies of GAPDH cortex, SVZ, and OB from P60 mice. $\boldsymbol{g}$, The integrin $\beta 1$ subunit was absent in extracts from the forebrain (including the RMS and surrounding tissue) of Itgb1-CNSko mice. wt, Wild type; mt, mutant. ${ }^{*} p<0.05$; ${ }^{* *} p<0.1 ;{ }^{* * *} p<0.01$.

$100-300 \mu \mathrm{m}$ in diameter. The explants were mixed into $70 \%$ of Matrigel (BD Biosciences), $2.4 \mathrm{mg} / \mathrm{ml}$ collagen type I (BD Biosciences), or 2.4 $\mathrm{mg} / \mathrm{ml}$ collagen type I plus $300 \mu \mathrm{g} / \mathrm{ml}$ laminin-1 (Sigma), kept at $37^{\circ} \mathrm{C} / 5 \% \mathrm{CO}_{2}$ for $7 \mathrm{~min}$ (for Matrigel experiments) and $1 \mathrm{~h}$ (for collagen experiments) without medium for polymerization, and then cultivated for $48 \mathrm{~h}$ at $37^{\circ} \mathrm{C} / 5 \% \mathrm{CO}_{2}$ in Neurobasal medium supplemented with B27 (Invitrogen) and penicillin/streptomycin. After $48 \mathrm{~h}$ in culture, explants were examined using a microscope, pictures were taken using a digital camera (Coolview; Nikon, Tokyo, Japan), and distances were measured using MetaMorph software as described previously (Hu and Rutishauser, 1996; Hu et al., 1996; Chazal et al., 2000). Migration distance was calculated as the distance in micrometers between the edge of the explant and the border of the cell migration front. The experiments were performed 
a

b

C

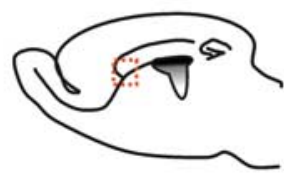

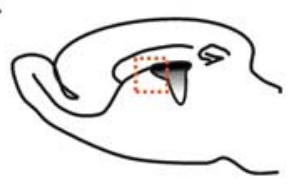
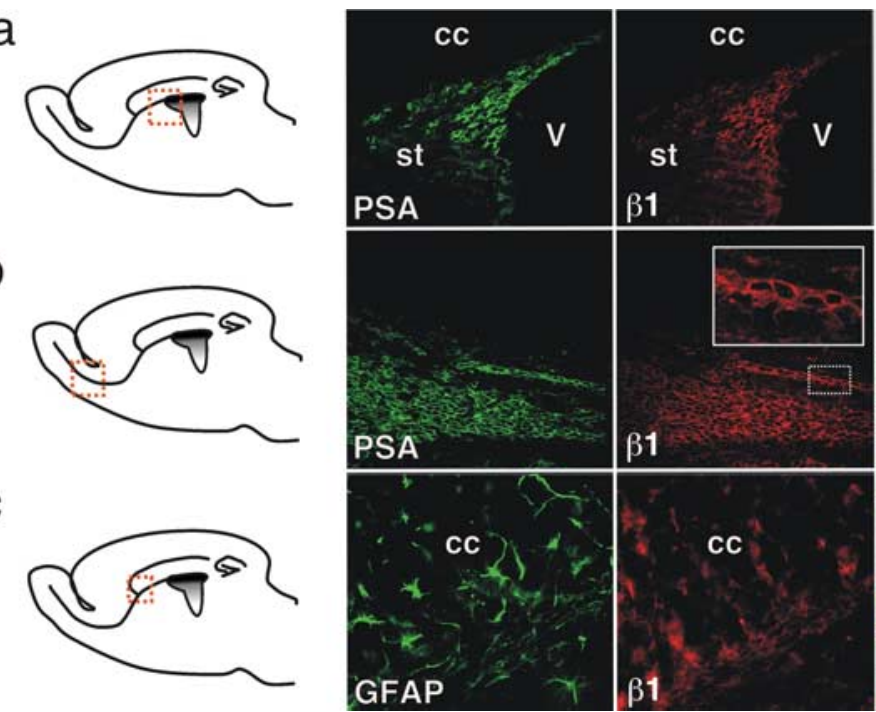

Figure 2. Analysis of the expression pattern of the $\beta 1$ integrin subunit. $\boldsymbol{a}-\boldsymbol{c}$, Sagittal sections at the level indicated in the diagrams were stained with antibodies to PSA (green) and the integrin $\beta 1$ subunit (red). $\beta 1$ integrins were highly expressed in PSA-positive neuroblasts. The inset in $\boldsymbol{b}$ shows a higher-magnification view of a cell chain demonstrating strong expression of $\beta 1$ integrins along the cell surface of neuroblasts. c, Sections were stained with antibodies to GFAP (green) and $\beta 1$ integrins (red). $\beta 1$ integrins expression was detected in some GFAP-positive cells. V, Ventricle; cc, corpus callosum; st, striatum. Scale bars: $\boldsymbol{a}, \boldsymbol{b}, 66$ $\mu \mathrm{m}$; inset in $\boldsymbol{b}, 23 \mu \mathrm{m} ; \boldsymbol{c}, 50 \mu \mathrm{m}$.

three times independently, with at least three explants per condition. For each explant, eight measurements were performed, and the data were pooled and are presented as cumulative frequency plots. For live video imaging, explants were cultivated in a humidified chamber at $37^{\circ} \mathrm{C} / 5 \%$ $\mathrm{CO}_{2}$, and pictures were taken every $5 \mathrm{~min}$ using a digital camera (Hamamatsu, Shizouka, Japan) and analyzed with MetaMorph Software.

Cell aggregation assays. The SVZ and rostral part of the RMS from 10 adult mice was dissected, and PSA-NCAM positive cells were isolated by FACS (see above). On average, 100,000 cells were recovered and used in cell aggregation assays. Cells were washed in $5 \mathrm{ml}$ of buffer $\mathrm{H}(20 \mathrm{~mm}$ HEPES, $140 \mathrm{~mm} \mathrm{NaCl}$, and $4 \mathrm{~mm} \mathrm{KCl}$ ), resuspended in buffer $\mathrm{H}$, and incubated in hanging droplets. When indicated, buffer $\mathrm{H}$ was supplemented during the aggregation assay with $2 \mathrm{mM} \mathrm{CaCl}_{2}$ and $100 \mu \mathrm{g} / \mathrm{ml}$ laminin-1 (Sigma). The hanging droplets were incubated for $20 \mathrm{~min}$ at $37^{\circ} \mathrm{C} / 5 \% \mathrm{CO}_{2}$, turned over, and incubated for $2 \mathrm{~h}$ at $37^{\circ} \mathrm{C} / 5 \% \mathrm{CO}_{2}$. Pictures were taken with a digital camera (Coolpix 990; Nikon). The number of single cells and the number of cells in aggregates were quantified. All values are derived from three independent experiments and are given as mean $\pm \mathrm{SE}$.

\section{Results}

$\beta 1$ and $\beta 5$ integrins are expressed in migrating neuroblasts in the RMS

To identify integrin subunits that are expressed in migrating type A neuroblasts, we isolated by FACS PSA-NCAM-positive cells from two distinct areas of the CNS (Fig. 1a). First, we isolated cells from the SVZ, in which cell proliferation is high and cells initiate migration. Second, we isolated cells from the distal RMS close to the $\mathrm{OB}$, in which cells are actively migrating. RNA was prepared and subjected to microarray analysis (for statistical analysis, see Material and Methods). As expected, PSA-NCAMpositive cells in the SVZ expressed markers for cell proliferation (e.g., PCNA) and for type A neuroblasts [e.g., Tau, Dcx (doublecortin), Dlx2 (distal-less homeobox 2), and mCD24 (the mouse cluster of differentiation 24)] (Fig. 1b). PSA-NCAMpositive cells from the distal part of the RMS showed a similar expression pattern, but some genes that are associated with proliferation in the SVZ (PCNA, mCD24, and Dlx2) were expressed in reduced amounts, whereas markers for differentiation such as
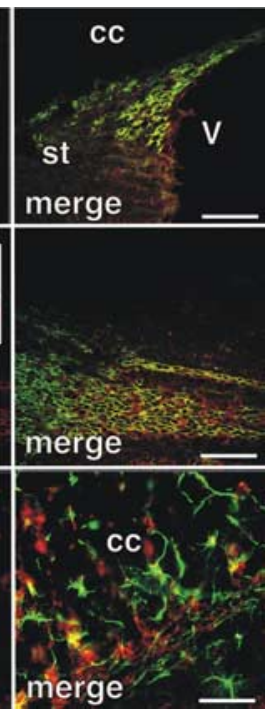

GABA receptor 2 were upregulated (Fig. $1 b)$. Genes specific for hematopoietic precursors or glial cells were not expressed, further confirming the quality of the FACS-sorted material (data not shown).

We next analyzed the expression of integrin subunits (Fig. $1 c, d$ ). Of the eight integrin $\beta$ subunits, only $\beta 1$ and $\beta 5$ were expressed at detectable levels (Fig. 1c). $\beta 1$ can heterodimerize with the integrin $\alpha 1-$ $\alpha 11$ subunits and with $\alpha v$, whereas $\beta 5$ forms heterodimers with $\alpha v$ only (Hynes, 2002). Most of these $\alpha$ subunits were detected in the SVZ and RMS (Fig. 1d). The expression of $\alpha 1, \alpha 6$, and $\alpha 7$ appeared to increase in the RMS when compared with the SVZ. These subunits heterodimerize with $\beta 1$ to form laminin receptors (Hynes, 2002), suggesting that the expression of several laminin receptors is increased during migration.

To confirm the expression of integrin subunit genes in type A neuroblasts and to obtain more reliable quantitative data for gene expression levels, we performed quantitative reverse transcription-PCR. We focused the analysis on the $\beta 1, \beta 3$, and $\beta 5$ subunits, as well as on those $\alpha$ subunits that heterodimerize with $\beta 1$ to form functional laminin receptors $(\alpha 1, \alpha 2, \alpha 3, \alpha 6$, and $\alpha 7)$ (Fig. 1e). Consistent with the results from microarray analysis, we observed expression of the integrin $\beta 1, \beta 5, \alpha 1, \alpha 3, \alpha 6$, and $\alpha 7$ subunits but very low levels of the $\beta 3$ and $\alpha 2$ subunits. The data also revealed increased expression for the $\alpha 6$ and $\alpha 7$ subunits in the distal part of the RMS when compared with the SVZ.

To evaluate expression of $\beta 1$ integrins in type A neuroblasts of adult mice at the protein level, we performed Western blots and immunohistochemistry experiments. $\beta 1$ protein was detected in extracts from the microdissected SVZ, OB, and control cerebral cortex (Fig. 1f). In sagittal sections from P60 mice, $\beta 1$ integrin expression was detected along the RMS from the SVZ to the OB (Fig. 2). Many $\beta 1$-positive cells were assembled into chains and expressed PSA-NCAM (Fig. 2; higher magnification in inset in $b$ ), confirming their identity as migratory type A neuroblasts. $\beta 1$ integrins was also expressed in some GFAP-positive glial cells along the RMS and in the corpus callosum (Fig. 2c). Unfortunately, antibodies against the murine integrin $\beta 5$ subunit were not of high enough quality to determine its distribution (data not shown).

\section{Defects in the RMS of mice lacking $\beta 1$ but not $\beta 5$ integrins in the CNS}

To determine the function of the $\beta 1$ and $\beta 5$ integrins in the RMS, we took a genetic approach. The integrin $\beta 5$ subunit gene (Itgb5) is not required for the viability of mice (Huang et al., 2000), allowing us to study the RMS in adult Itgb5-null mice. We analyzed three mutant mice by histology at different levels along the rostral migratory stream and within the OB. We could not detect a defect in the organization of the RMS and OB in the mutants (Fig. $3 a, b$ and data not shown). We next analyzed integrin $\beta 1$ deficient mice. Because mice with a null mutation in the integrin $\beta 1$ gene (Itgb1) die during embryogenesis, we took advantage of a mouse line carrying an Itgb $1^{\text {flox }}$ allele (Graus-Porta et al., 2001) and a nestin-CRE mouse line (Tronche et al., 1999). We have 
shown that the nestin-CRE mouse line expresses CRE in neural progenitors in the developing CNS (Graus-Porta et al., 2001). To evaluate the activity of the CRE transgene during adult neurogenesis, we crossed nestin-CRE mice with a reporter mouse line that carries a Rosa26lac $Z^{\text {flox }}$ transgene. In this mouse line, LacZ expression is activated by CRE recombination (Mao et al., 1999). Staining for LacZ confirmed that the majority of cells in the SVZ and RMS had undergone CRE-mediated recombination, and double staining for LacZ and PSA-NCAM confirmed that recombination occurred in most, if not all, type A neuroblasts (data not shown). Complete recombination in all cells in the RMS, including neuroblasts and glial cells was expected because the nestin gene is expressed in the precursors of neurons and glia in the developing and adult brain (Lendahl et al., 1990; Graus-Porta et al., 2001; Merkle et al., 2004; Kuo et al., 2006).

We next crossed Itgb1 ${ }^{+/-}$nestin$C R E^{+/-}$mice with $\operatorname{Itg} b 1^{\text {flox/flox }}$ mice. To confirm that the Itgbl gene was inactivated in the mutant offspring (referred to as Itgb1-CNSko mice), we stained sagittal sections from adult mouse brains with antibodies to integrin $\beta 1$. As expected, $\beta 1$ expression was abolished in the RMS of Itgb1-CNSko mice (Fig. $1 g$ and data not shown). We next stained sections with Nissl. In control mice, neuroblasts in the RMS formed compact chains (Fig. $3 c-e$ ). In Itgb1-CNSko mice, the RMS was present, but it appeared less compact and the cells were no longer assembled into chains (Fig. $3 c, d$ ). This was particularly evident in high-magnification views (Fig. $3 e$ ). Together, our findings show that the RMS is severely perturbed in the absence of $\beta 1$ but not $\beta 5$ integrins.

Defects in the size of the OB and in cell migration in Itgb1-CNSko mice

The defect in the morphology of the RMS in Itgb1-CNSko mice suggests that neuroblasts may traverse the RMS less efficiently, which could affect the number of cells that reach the OB. In addition, cell proliferation or survival may be affected. We therefore analyzed the size and morphology of the OB in wild-type and mutant animals, and we analyzed cell proliferation, survival, and migration. First, we prepared serial sections of the $\mathrm{OBs}$ and determined its volume (Fig. 4). The OB in Itgb1-CNSko mice was significantly reduced in size (OB volume: wild type, $6.02 \pm 0.14 \mathrm{~mm}^{3}$; Itgb1CNSko, $4.61 \pm 0.39 \mathrm{~mm}^{3}$ ), but the organization of different cell layers was not changed (Fig. $4 a$ ), suggesting that neuroblasts that reached the $\mathrm{OB}$ switched normally from tangential to radial mi-
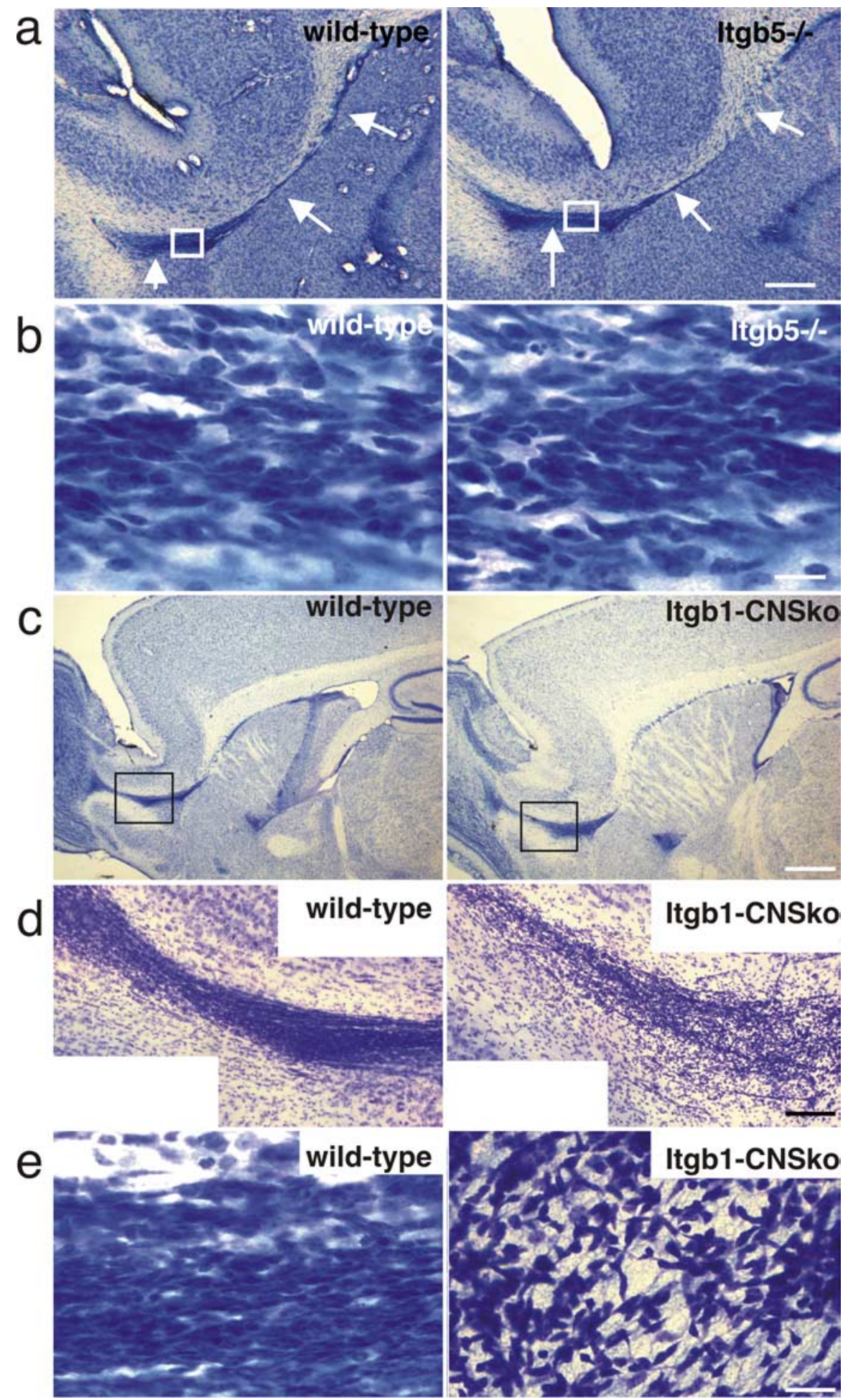

Figure 3. Defects in the organization of the RMS in mice lacking $\beta 1$ but not $\beta 5$ integrins. Sagittal brain sections were prepared from mice of the indicated genotype at P60, and the sections were stained with Nissl. $\boldsymbol{a}, \boldsymbol{b}$, The RMS (arrows) in Itgb5-null mice did not show any obvious morphological defect when compared with wild-type mice. $\boldsymbol{b}$ shows higher-magnification views of the areas boxed in $\boldsymbol{a}$. Chains of migrating cells were clearly visible. $\boldsymbol{c}, \boldsymbol{d}$, The RMS was detectable in Itgb1-CNSko mice. The higher-magnification views in $\boldsymbol{d}$ of the area boxed in crevealed that the RMS in Itgb1-CNSko mice appeared less well organized and compacted than in wild-type mice.e, At even higher magnification, it was apparent that cells in the RMS of Itgb1-CNSko mice were not arranged in organized chains along the rostrocaudal extension of the RMS. Scale bars: $\boldsymbol{a}, 225 \mu \mathrm{m} ; \boldsymbol{b}, 23 \mu \mathrm{m} ; \boldsymbol{c}, 600 \mu \mathrm{m} ; \boldsymbol{d}, 90 \mu \mathrm{m} ; \boldsymbol{e}, 45 \mu \mathrm{m}$. gration and differentiated into interneurons. Next, we analyzed cell death and proliferation. Staining with antibodies to caspase 3 revealed only very few cells undergoing apoptosis, and there was no apparent increase in the number of caspase 3-positive cells in 

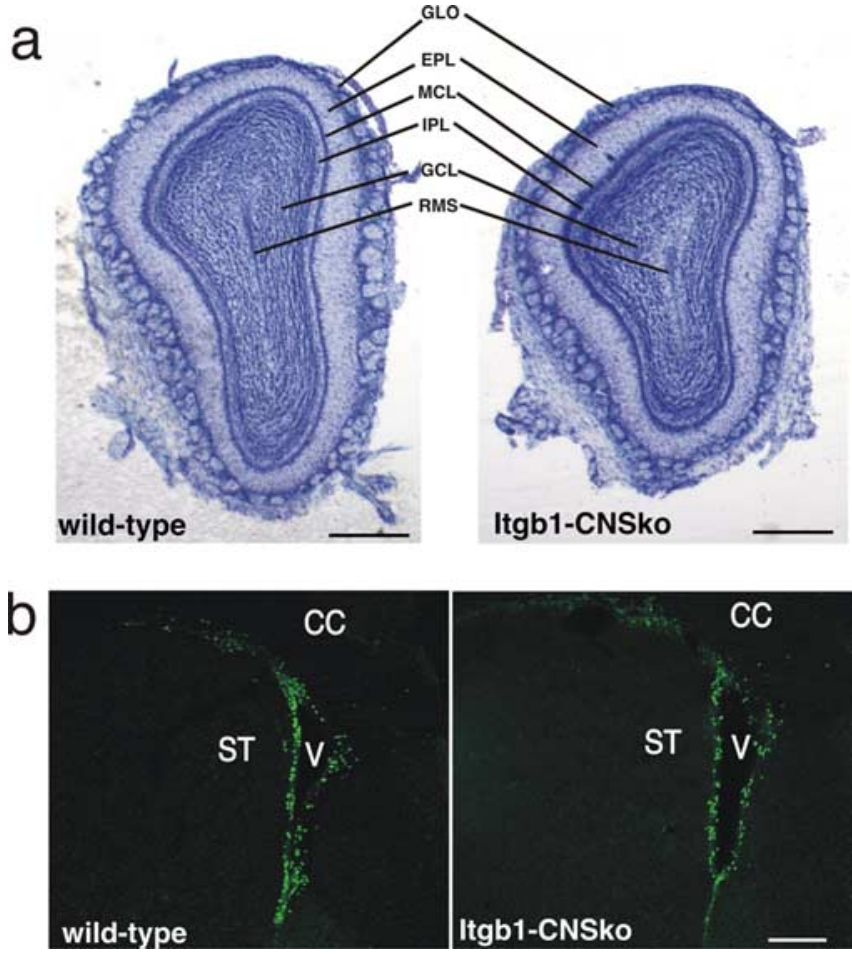

Figure 4. Cell proliferation is not affected in Itgb1-CNSko mice. $\boldsymbol{a}$, Coronal sections through the $0 \mathrm{~B}$ of adult mice were stained with Nissl. The overall organization of the $0 \mathrm{~B}$ was not altered, and cell layers were clearly distinguishable in Itgb1-CNSko mice. GLO, Glomerular layer; EPL, external plexiform layer; $M C L$, mitral cell layer; IPL, internal plexiform layer; $G C L$, granule cell layer; RMS, rostral migratory stream. $\boldsymbol{b}$, Sagittal sections were prepared $1 \mathrm{~h}$ after injecting mice with BrdU, and the sections were stained with antibodies to BrdU (green). Proliferating cells were prominent in the SVZ in wild-type and mutant animals. V, Ventricle; CC, corpus callosum; ST, striatum. Scale bars: $\boldsymbol{a}, 385 \mu \mathrm{m} ; \boldsymbol{b}, 200 \mu \mathrm{m}$.

the mutant mice (data not shown). To evaluate cell proliferation, sagittal sections of the brain were prepared $1 \mathrm{~h}$ after injection with BrdU. The number of BrdU-positive cells in the SVZ, the main proliferative zone, was determined. Care was taken to quantify cells at the same histological level in wild-type and mutant mice. We did not observe a difference in the number of BrdU-positive cells in the SVZ of Itgb1-CNSko mice (BrdU-positive cells: wild type, $125.5 \pm 9.1$; Itgb1-CNSko, $125 \pm 5.79$ ). We conclude that defects in cell proliferation and apoptosis are primarily not responsible for perturbations in the RMS and OB of Itgb1-CNSko mice.

To analyze cell migration, we determined the distribution of BrdU-positive cells 7 and $21 \mathrm{~d}$ after a single BrdU pulse (Fig. 5). We quantified the number of BrdU-positive cells in the proximal and distal RMS and in the granule cell layer in the OB (noted as regions 1, 2, and 3 in Fig. $5 a-c, e)$. At $7 \mathrm{~d}$ after the BrdU pulse, the vast majority of BrdU-positive cells in wild-type mice had entered the RMS but had not reached the OB (Fig. 5b,c). In Itgb1-CNSko mice, there was an approximate threefold reduction of BrdUpositive cells in the RMS, indicating that a reduced number of cells had migrated into the RMS (Fig. 5b,c). In addition, many BrdU-positive cells had migrated out of the RMS into the surrounding tissue (Fig. 5b, arrows). The absolute number of the ectopically migrating cells was difficult to quantify but likely contributed significantly to the reduction of BrdU-positive cells within the RMS. At $21 \mathrm{~d}$, the majority of BrdU-positive cells in wild-type mice had left the RMS and reached the granule cell layer in the OB (Fig. 5e). In Itgb1-CNSko mice, reduced number of cells had reached the granule cell layer, and increased numbers of BrdU-positive cells remained in the RMS (Fig. 5e). This was also evident in coronal sections. Few BrdU-positive cells were present in the RMS of wild-type mice (Fig. $5 d$ ), whereas many had reached the granule cell layer (Fig. $5 d$, inset). In contrast, BrdU-positive cells were prominent in the RMS of Itgb1-CNSko mice (Fig. $5 d$ ) and few in the granule cell layer (Fig. $5 d$, inset). Together, these findings suggest that cell migration from the SVZ to the $\mathrm{OB}$ is impaired but not abolished in Itgb1-CNSko mice. Interestingly, staining of $\mathrm{OB}$ sections with calretinin antibodies revealed radially migrating cells, containing long leading process oriented perpendicular to the surface of the OB (Fig. 5f). Although we cannot exclude that $\beta 1$ integrins may control some aspects of radial migration, the findings show that cells that have migrated through the RMS and reached the OB switch from tangential to radial migration and populate appropriate cell layers in the OB.

\section{Formation of cell chains and the glial tubes}

We next determined the cause for the defect in cell migration in Itgb1-CNSko mice. Type A neuroblasts in the RMS migrate as chains within glial tubes (Lois et al., 1996). The expression of $\beta 1$ integrins in neurons and glia suggested that they control the formation/maintenance of cell chains and/or the glial tubes. Staining of sections with antibodies to PSA-NCAM demonstrated that cell chains were altered in the mutants. In sagittal sections, neuroblasts still seemed to cluster, but cells were not aligned into chains extending along the rostrocaudal axis of the RMS (Fig. 6a). In coronal sections, PSA-NCAM-positive cells in wild-type mice were visible as clusters, whereas cells in the mutants were scattered (Fig. 6b). Staining with GFAP revealed that the glial tubes were also disrupted in the mutants. In wild-type mice, GFAPpositive glial cells were in close apposition to the RMS, but they were more widely distributed in the mutants (Fig. $6 c, d$ ).

These findings were confirmed at the ultrastructural level on coronal sections of the RMS (Fig. 7a-c). Type A neuroblasts can be identified by their small cytoplasm and big dark nuclei occupying the majority of the cell body; astrocytes are characterized by their light cytoplasm containing dense bodies (Doetsch et al., 1997). In the RMS of control mice, type A neuroblasts were attached to each other and formed dense clusters that were often associated with one or two astrocytes (Fig. 7a,b). In Itgb1-CNSko mice, neuroblasts were dispersed and only occasionally formed contacts with each other (Fig. $7 a, b$ ), but they maintained contacts with astrocytes. This was particularly evident in highmagnification views (Fig. 7c). As reported previously, electrondense material of uncharacterized composition is present at the contact zone between neuroblasts in wild-type mice (Doetsch et al., 1997). Electron-dense patches were rarely observed in Itgb1CNSko mice, whereas tight junctions between neuroblasts and astrocytes were preserved (Fig. 7c). These findings suggest that the electron-dense patches between neuroblasts may be integrindependent adhesion complexes that are specifically affected in Itgb1-CNSko mice. However, the overall integrity of the glial tubes is perturbed in Itgb1-CNSko mice, suggesting that contacts between glial cells are also affected. Overall, the findings suggest that defects in both the formation of cell chains and the glial tubes likely contribute to the migratory defect in the RMS of Itgb1CNSko mice.

\section{Functions of $\beta 1$ integrins in the formation of cell chains} The expression of $\beta 1$ integrins in migrating neuroblasts suggest that they control their migratory behavior directly. To test for 
functions of $\beta 1$ integrins in the formation and movement of cell chains, we cultivated SVZ explants in Matrigel. In this assay, cells from wild-type mice emigrate as cell chains independently of a glial scaffold (Wichterle et al., 1997). Consistent with previous observations, we observed cell chains in explants derived from wild-type mice (Fig. $8 a, b$ ). In contrast, cells in explants prepared from Itgb1-CNSko mice did not form chains and migrated as single cells (Fig. $8 c, d$ ). A quantification of the distance traveled by $48 \mathrm{~h}$ revealed no difference for cells in explants from wild-type and mutant mice (Fig. 8e). We next monitored the dynamics of cell migration by time-lapse video microscopy. Wild-type cells migrated along each other in tightly linked chains, in which the leading cell developed one or multiple processes (Fig. 9a) (supplemental Movie 1, available at www. jneurosci.org as supplemental material). In contrast, cells from mutant animals migrated as single cells and formed one or several leading processes ending in growth cones that appeared to explore the environment (Fig. 9b) (supplemental Movie 2, available at www.jneurosci.org as supplemental material). After a phase of leading process extension, the cell bodies translocated toward the tips of the processes (Fig. $9 b$, cell marked with an arrowhead). Unlike wild-type cells, which appeared to migrate directionally away from the explant, the movement of $\beta 1$-deficient cells appeared more random, and cells even reversed the direction of migration (Fig. $9 b$, cell marked by arrowhead). Together, our data show that $\beta 1$ integrins are not required for the migration of neuroblast into Matrigel. Instead, $\beta 1$ integrins control the mode of migration. In the absence of $\beta 1$ integrins, most of the cells appear to migrate in a mode similar to the leading cell in chains, but individual cells no longer form stable contact with each other to form cell chains. a

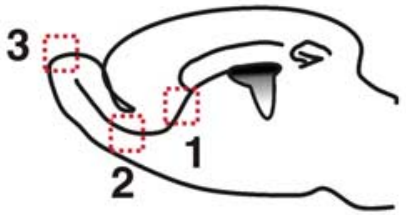

C

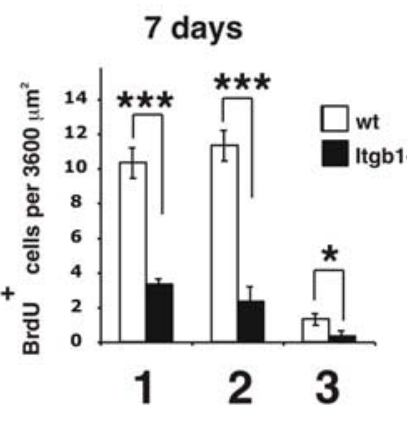

e

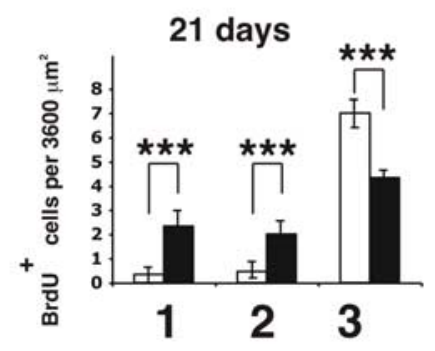

b

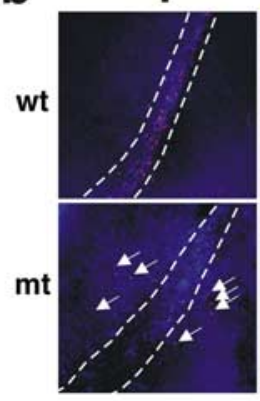

2

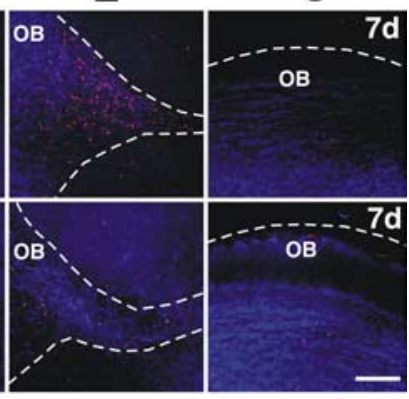

d
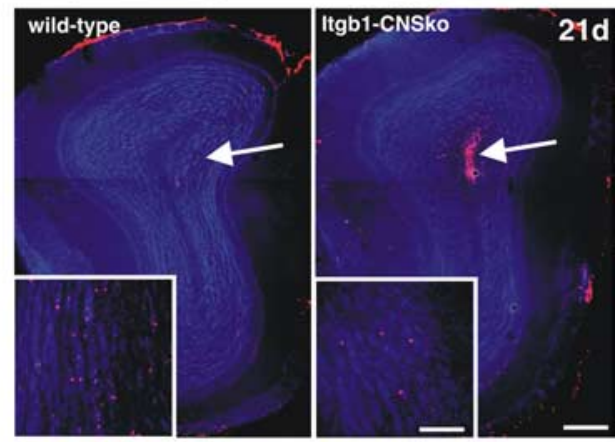

$\mathbf{f}$
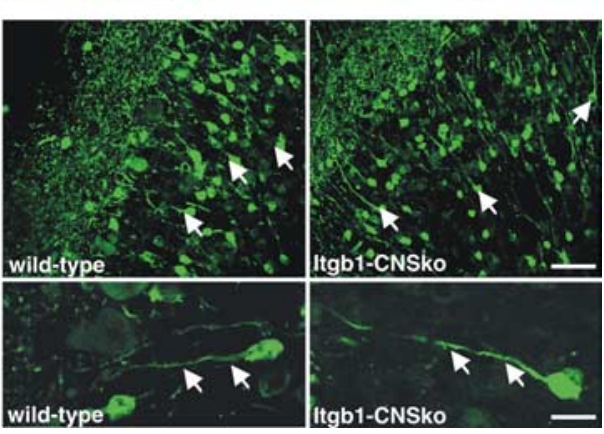

Figure 5. Defects in cell migration in Itgb1-CNSko mice. $\boldsymbol{a}-\boldsymbol{d}$, Adult mice were injected with BrdU, and sagittal brain sections were prepared 7 and $21 \mathrm{~d}$ later. The sections were stained with DAPI (blue) to reveal nuclei and with antibodies to BrdU (red). $\boldsymbol{a}$, The number of BrdU-positive cells was quantified in the areas labeled with 1, 2, and 3. $\boldsymbol{b}$, Representative images showing BrdU-labeled cells in areas 1, 2, and 3 after $7 \mathrm{~d}$. The boundaries of the RMS and OB are outlined with dashed lines. The arrows indicate BrdU-positive cells in mutant mice that had migrated out of the RMS into surrounding tissue. c, Quantification of the number of BrdU-positive cells $7 \mathrm{~d}$ after BrdU injection in areas 1, 2, and 3. ${ }^{*} p<0.5{ }^{* * *} p<0.01$. $d$, At $21 \mathrm{~d}$ after BrdU labeling, coronal sections at the level of the $O B$ were prepared and stained with DAPI (blue) and antibodies to BrdU (red). Note the accumulation of BrdU-positive cells in the RMS in the center of the $O B$ in the mutants. The insets show higher-magnification views of the granule cell layer. $e$, Quantification of the number of BrdU-positive cells in areas 1, 2, and 3 at $21 \mathrm{~d}$ after BrdU labeling. ${ }^{* * *} p$ $<0.01$.f, Sagittal sections through the $O B$ were stained with antibodies to calretinin (green) to reveal radially migrating neurons. Note that cells with the typical morphology of radially migrating cells were visible (arrows). The bottom row shows highermagnification view of radially migrating neurons containing long leading processes (arrows). Scale bars: $\boldsymbol{b}, 140 \mu \mathrm{m} ; \boldsymbol{d}, 250 \mu \mathrm{m}$; inset in $\boldsymbol{d}, 88 \mu \mathrm{m} ; \boldsymbol{f}$, top row, $80 \mu \mathrm{m} ; \boldsymbol{f}$, bottom row, $16 \mu \mathrm{m}$.

\section{Formation of cell chains depends on laminin}

Integrins may control chain formation by binding to counter receptors on adjacent neuroblasts or by binding to ECM glycoproteins that are deposited between neuroblasts. Because integrins that interact with laminin are upregulated during migration (Fig. 1), we analyzed the distribution of laminin within the RMS. Different laminin isoforms have been described that are formed by the assembly of different $\alpha, \beta$, and $\gamma$ subunits into heterotrimeric molecules (Miner and Yurchenco, 2004). In our microarray analysis, we observed prominent expression of several lami$\operatorname{nin} \alpha, \beta$, and $\gamma$ subunits in the RMS, including the $\alpha 1, \alpha 2$, and $\alpha 4$ subunits (data not shown). To confirm the expression of laminins in the RMS, we stained sagittal sections with available antibodies that recognize the laminin $\alpha 1$ and $\alpha 2$ subunits. We ob- served prominent staining in the SVZ and RMS of adult mice (Fig. 10a,b). Higher-magnification views showed that the laminin subunits were concentrated around the surface of PSANCAM-expressing neuroblasts in cell chains (Fig. 10c-e). Together, our microarray analysis and immunohistochemistry data show that several laminin subunits are expressed in the RMS and are appropriately localized to mediate interactions between neuroblasts.

To analyze whether laminins are required for the formation of cell chains, we next analyzed the RMS in mice with mutations in laminin subunit genes. We focused our studies on laminin $\alpha 2$ and $\alpha 4$-deficient mice, because both $\alpha$ subunits are expressed in the adult RMS (Fig. 10 and data not shown). Furthermore, the mutant mice survive to postnatal ages (unlike other mice with 

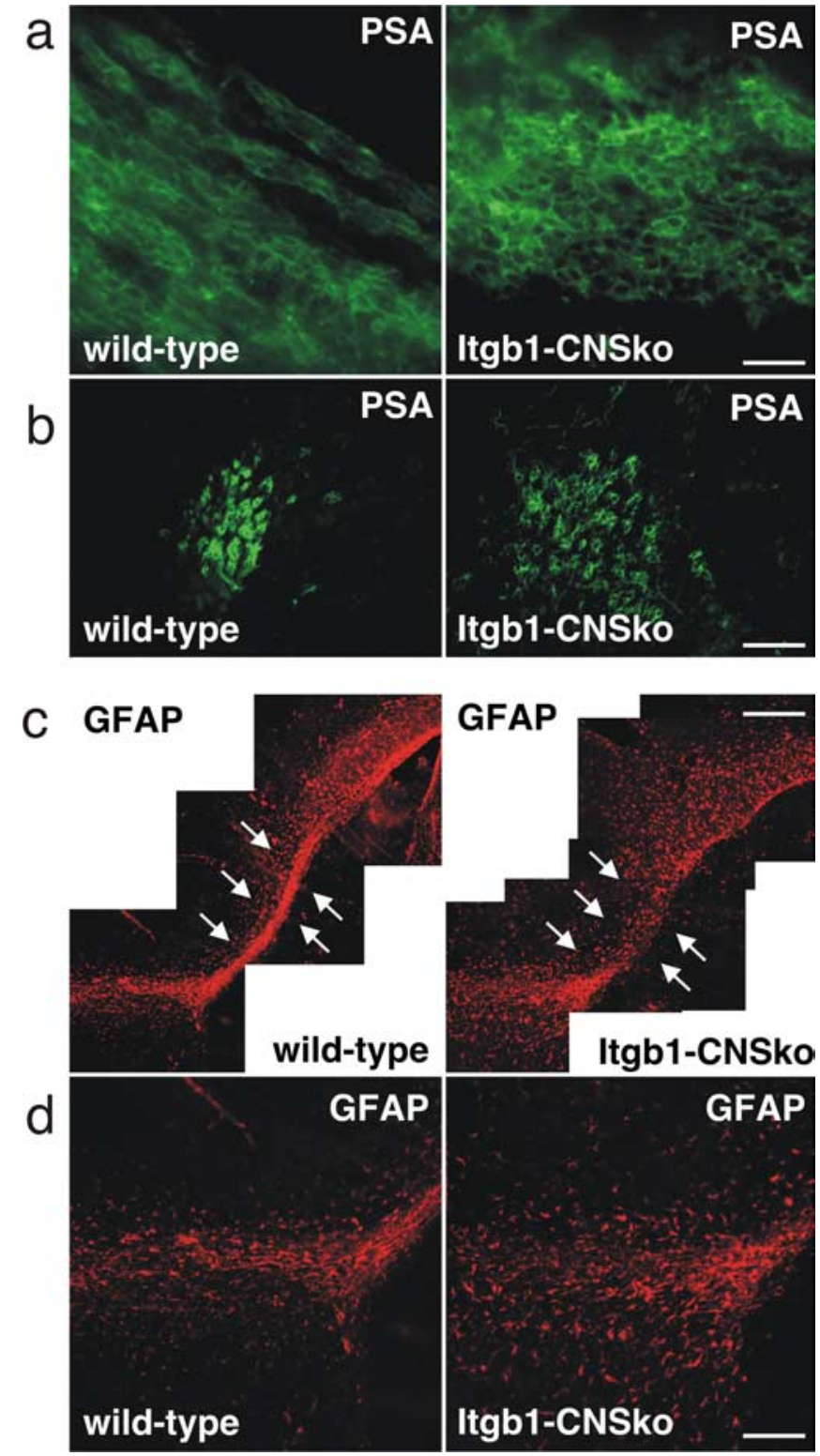

Figure 6. Itgb1-CNSko mice show defects in the formation of cell chains and disruption of the glial tubes. $\boldsymbol{a}$, Sagittal sections through the RMS of adult mice were stained with antibodies to PSA-NCAM (green) to reveal migrating neuroblasts. Although neuroblasts in wild-type mice were assembled into chains along the rostrocaudal axis of the RMS, cells in the mutant mice appeared less well organized and did not form clearly recognizable chains. $\boldsymbol{b}$, Coronal sections through the RMS of adult mice were stained with PSA-NCAM antibodies. Neuroblasts in Itgb1CNSko mice were more widely dispersed than in wild-type mice. $\boldsymbol{c}, \boldsymbol{d}$, Sagittal sections through the RMS of adult mice were stained with antibodies to GFAP (red) to reveal the glial tubes. The glial tubes were far less obvious in Itgb1-CNSko than in wild-type mice. Scale bars: $\boldsymbol{a}, 30 \mu \mathrm{m} ; \boldsymbol{b}$, $100 \mu \mathrm{m} ; \boldsymbol{c}, 440 \mu \mathrm{m} ; \boldsymbol{d}, 200 \mu \mathrm{m}$.

mutations in laminin subunit genes such as laminin $\alpha 1-, \beta 1-$, and $\gamma 1$-deficient mice) (Miner and Yurchenco, 2004), allowing an analysis of the RMS in adult mice. Mice with mutation in either the laminin $\alpha 2$ or $\alpha 4$ subunit genes did not show any defects in the formation of the RMS (data not shown). However, $\alpha 2 / \alpha 4$ double-mutant mice showed defects in the RMS. Although the RMS could be detected in the mutants (Fig. 10f,g) and cell chains were visible in some animals, the overall organization of the RMS was far less compact (Fig. 10h,i). Many of the cells did not assemble into cell chains (Fig. 10j,k). Because the laminin $\alpha 2$ subunit is a component of the laminin-2, -4 , and -12 isoforms whereas the a
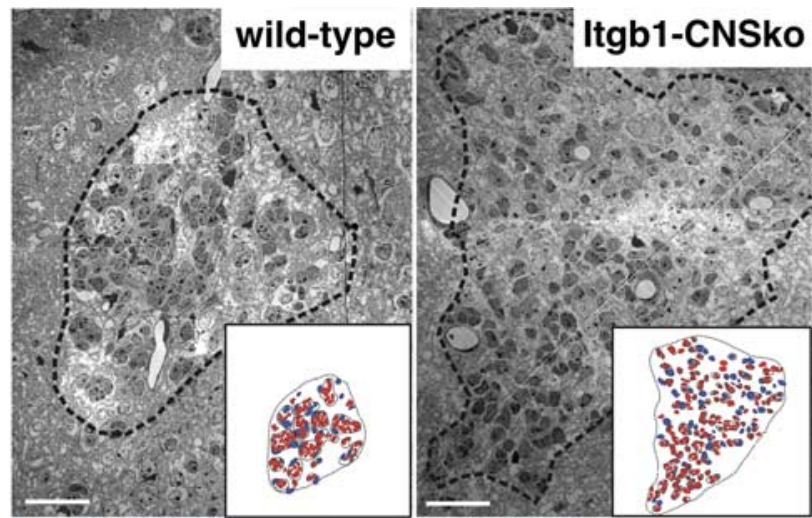

b
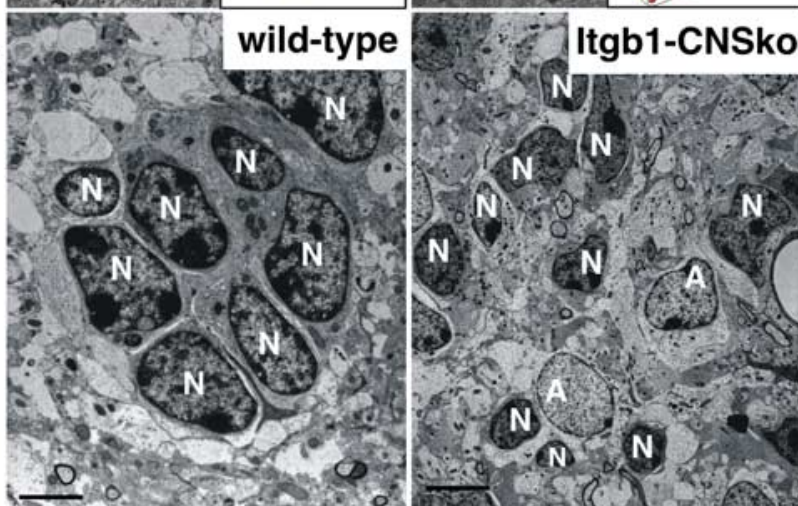

C
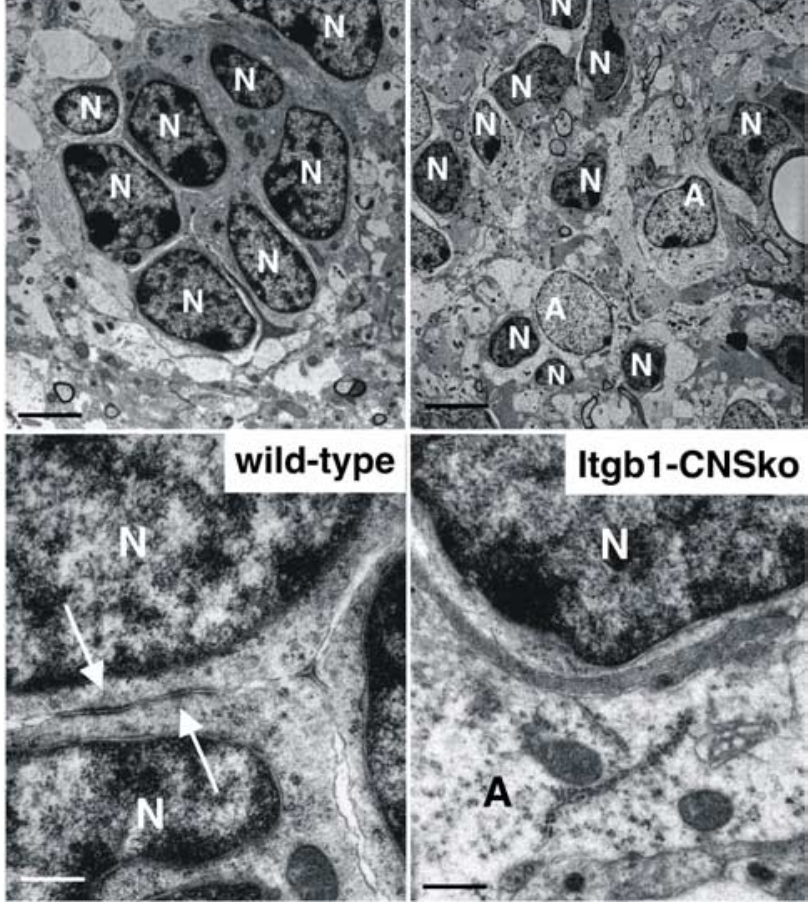

Figure 7. Disruption of interactions between neuroblasts in Itgb1-CNSko mice. $\boldsymbol{a}$, Coronal sections through the RMS were analyzed by electron microscopy. Cells in mutant mice were dispersed far more than in wild-type mice. The inset shows the cells color coded (neuroblasts in red, astrocytes in blue). $\boldsymbol{b}$, Higher-magnification views show that, although neuroblasts (N) formed tight clusters in wild-type mice, they were dispersed in the mutants and astrocytes (A) were interspersed between the neuroblasts. c, In wild-type mice, typical contact zones between neuroblasts were apparent (arrow). In Itgb1-CNSko mice, neuroblasts and astrocytes still tightly aligned their membranes. Scale bars: $\boldsymbol{a}, 66 \mu \mathrm{m} ; \boldsymbol{b}, 7$ and $13 \mu \mathrm{m} ; \boldsymbol{c}, 1 \mu \mathrm{m}$.

$\alpha 4$ subunit is a component of the laminin-8 and -9 isoforms (Miner and Yurchenco, 2004), our findings suggest that several of these isoforms have redundant functions in the formation of cell chains in the RMS.

To further define the function of laminin for the formation of cell chains, we analyzed chain formation in SVZ explants. Previous studies have shown that the formation of cell chains that emigrate from SVZ explants is dependent on the in vitro environment. Cell chains form in Matrigel (which contains laminin) but not in collagen gels (which do not contain laminin) (Wichterle et al., 1997). Unfortunately, laminin alone does not polymerize into three-dimensional matrices. Therefore, to test whether laminin can induce chain migration, we explanted the SVZ from wildtype mice into mixed collagen/laminin gels. We used for this 
purpose laminin-1, which is expressed in the RMS (Fig. 10) and readily available as a purified molecule. As a control, we prepared SVZ explants in collagen gels without laminin-1. Cells in collagen gels migrated as single cells and showed a similar morphology and migrational behavior to integrin $\beta 1$-deficient cells in Matrigel (Fig. $11 a)$. The cells formed single or multiple leading processes that were tipped with growth cones. In contrast, cells in mixed collagen/laminin-1 gels migrated as chains (Fig. 11b). Although the chains were similar in morphology to those in Matrigel, the chains seemed less compact. In addition, cells in mixed collagen/laminin-1 gels migrated at reduced speed when compared with cells in collagen gels, suggesting that the formation of cell chains reduced the speed of migration (Fig. 11c).

To test directly whether laminin-1 promotes cell-cell interactions between neuroblasts, we performed short-term cell aggregation assays. PSA-NCAM-positive neuroblasts were isolated by FACS, and cell aggregation was quantified $2 \mathrm{~h}$ after the addition of laminin-1 (Fig. 11d,e). Because interactions of integrins with laminin-1 are dependent on divalent cations, we performed the experiments in the presence or absence of $\mathrm{Ca}^{2+}$. FACS-sorted PSA-NCAM-positive cells in buffer without $\mathrm{Ca}^{2+}$ formed few if any aggregates. When the cells were incubated in buffer containing $\mathrm{Ca}^{2+}$, aggregates formed that consisted predominantly of two cells. In the presence of both $\mathrm{Ca}^{2+}$ and laminin-1, the cells formed many more and larger aggregates. Aggregates were visible after 20 min (data not shown) but were more prominent after $2 \mathrm{~h}$ (Fig. 11d,e). Together, our experiments provide strong evidence that laminin is critical for the formation of cell chains in the RMS.

\section{Discussion}

We provide here several lines of evidence that $\beta 1$ integrins and their laminin ligands control the formation of cell chains in the RMS of adult mice. First, we show that $\beta 1$ integrins and several laminins are expressed in the appropriate pattern to support chain formation. Second, functional data show that $\beta 1$ integrins are required for chain formation in vivo and in vitro. Third, laminin induces the aggregation of PSANCAM-positive neuroblasts and it promotes chain migration in reconstituted collagen/laminin matrices, and laminin $\alpha 2 / \alpha 4$ double-mutant mice show altered migration in the RMS. Surprisingly, although $\beta 1$ integrins are required for the formation of cell chains, $\beta 1$-deficient neuroblasts still migrate from the SVZ to the $\mathrm{OB}$. These results suggest that $\beta 1$ integrins and their laminin ligands promote the formation of cell chains, whereas additional receptors are important for cell motility independently of chain formation. In addition, the glial tubes are disrupted in Itgb1CNSko mice, suggesting additional functions for integrins and their laminin ligands, for example in mediating interactions between glial cells.

\section{$\boldsymbol{\beta} 1$ integrins and the formation of cell chains}

Previous studies have identified several receptor molecules that control chain migration in the RMS, such as PSA-NCAM, which controls interactions of neuroblasts with the stationary environment through which the cells migrate (Tomasiewicz et al., 1993; Cremer et al., 1994; Ono et al., 1994; Hu et al., 1996; Chazal et al., 2000) and members of the EphB and ErbB receptor family that affect neuroblast proliferation and migration (Conover et al., 2000; Anton et al., 2004; Ghashghaei et al., 2006). However, the molecules that link neuroblasts into chains have remained elusive. The data presented here now provide strong evidence that $\beta 1$ integrins are important to link neuroblasts into chains. $\beta 1$ integrins are expressed on the surface of migrating neuroblasts in 
a
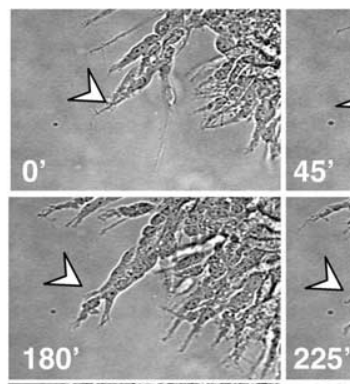
$45^{\prime}$
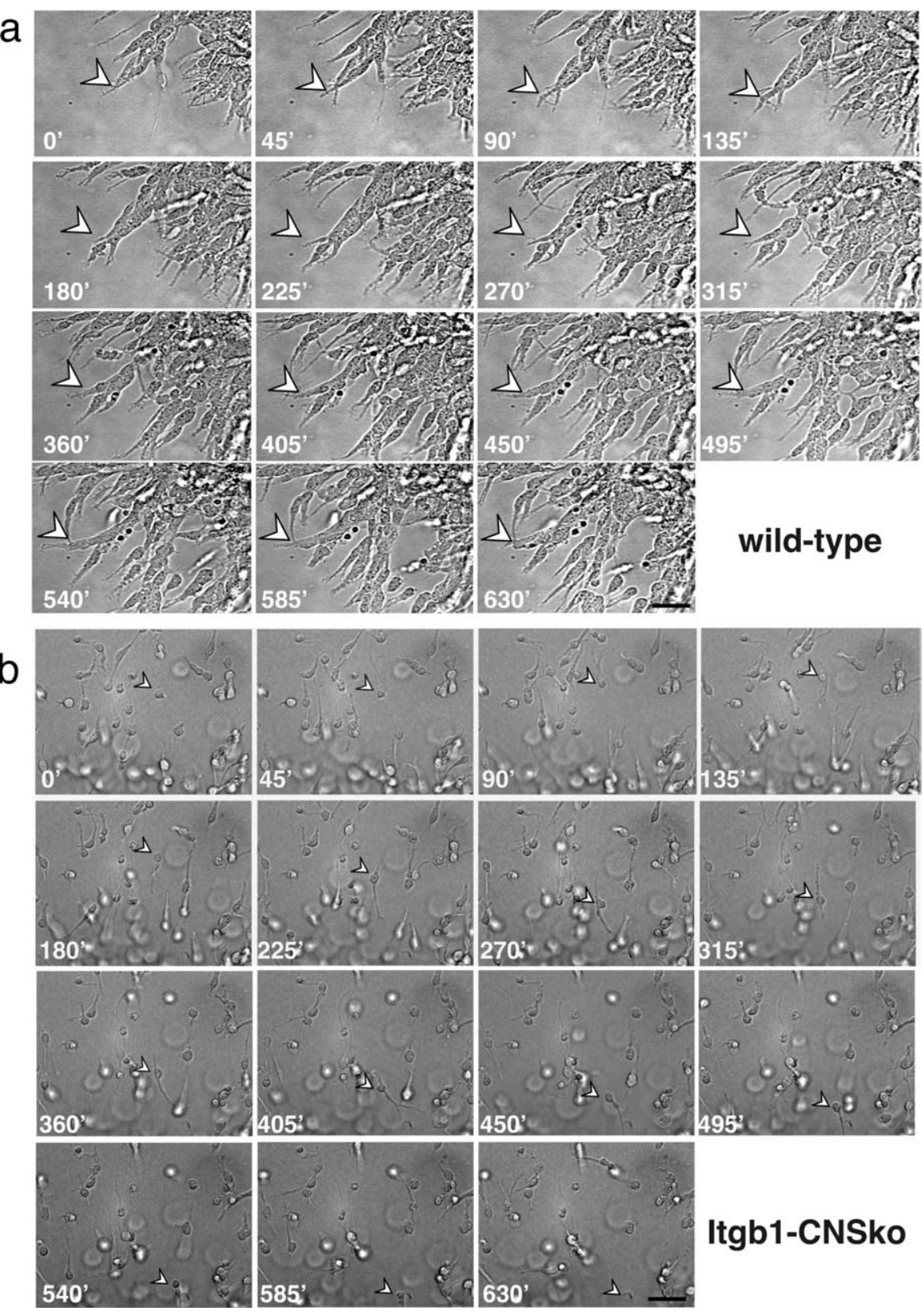

Itgb1-CNSko

Figure 9. Pictures of time-lapse video images of migration assays in Matrigel. The migration of neuroblasts was followed by time-lapse video microscopy (supplemental Movies 1, 2, available at www.jneurosci.org as supplemental material). Pictures from sequential time points (indicated in minutes) are shown. $\boldsymbol{a}$, A chain of migrating neuroblasts in wild-type mice is marked with an arrowhead. The leading cell developed several protrusions and moved beyond the arrowhead. At $\sim 315 \mathrm{~min}$, the tip of the chain started to split and cells advanced along two separate pathways. $\boldsymbol{b}$, Cells in explants from Itgb1-CNSko mice migrated as single cells. The cell marked by the arrowhead formed a leading process, and the cell body translocated along the process toward the tip of the leading process. At $180 \mathrm{~min}$, a new leading process developed at the opposite end of the cell body, and the cell started to reverse its direction of migration. Scale bars: $\boldsymbol{a}, 46 \mu \mathrm{m} ; \boldsymbol{b}, 58 \mu \mathrm{m}$.

cell chains, and chain formation is disrupted in Itgb1-CNSko mice. At the light microscopic level, $\beta 1$-deficient neuroblasts are in close proximity to each other, but they are not assembled into chains along the rostrocaudal axis of the RMS. Ultrastructural studies confirm that contacts between migrating neuroblasts are disrupted in the absence of $\beta 1$ integrins. In contrast, contacts between neuroblasts and astrocytes are maintained. In vitro data provide evidence that $\beta 1$ integrins act at least in part in neuroblasts to link them into chains: although $\beta 1$-deficient cells still migrate from SVZ explants into Matrigel, the cells no longer form chains and instead migrate as single cells. wild-type

We also provide first insights into the mechanism by which $\beta 1$ integrins control chain formation. $\beta 1$ integrins are receptors for ECM molecules including laminins. Several integrins that bind laminins $(\alpha 1 \beta 1, \alpha 2 \beta 1, \alpha 3 \beta 1, \alpha 6 \beta 1$, and $\alpha 7 \beta 1)$ are expressed in migrating neuroblasts. Likewise, several laminins are expressed in the RMS, and the formation of cell chains is perturbed in laminin $\alpha 2 / \alpha 4$ doublemutant mice. In vitro, purified laminin can induce the aggregation of neuroblasts, and neuroblasts migrate as chains in mixed collagen/laminin gels, whereas collagen alone promotes migration but not chain formation. The simplest interpretation of our results is that $\beta 1$ integrins in neuroblasts bind to laminin to link the cells into chains. This could be achieved by different mechanisms. Although the integrins $\alpha 3 \beta 1, \alpha 6 \beta 1$, and $\alpha 7 \beta 1$ bind to the same site in laminin, the integrins $\alpha 1 \beta 1$ and $\alpha 2 \beta 1$ bind to an additional site (Miner and Yurchenco, 2004). Therefore, neuroblasts could be linked to each other by integrins on the surface of adjacent cells that bind to distinct sites in a single laminin molecule. Alternatively, because laminin assembles into networks (Miner and Yurchenco, 2004), integrins on adjacent neuroblasts may interact with multiple binding sites within a macromolecular laminin matrix. This latter model shows striking parallels to the mechanisms by which integrins control cellular interactions in Drosophila, in which different integrins on muscle and tendon link the cells via an ECM network to each other (Bokel and Brown, 2002).

Although laminin is able to restore chain migration of wild-type cells in collagen gels, the chains appear less compact and move with reduced speed when compared with cell chains in Matrigel. These findings suggest that, although $\beta 1$ integrins and laminins initiate chain formation, other receptors and signaling molecules cooperate with $\beta 1$ integrins and laminins to control the behavior of neuroblasts in chains. As one possibility, additional ECM glycoproteins may be required for chain formation. Our data already suggest that laminin isoforms containing the laminin $\alpha 2$ and $\alpha 4$ subunits are involved, but our data also show that additional laminin subunits are expressed in the RMS. Several isoforms may cooperate with each other or with additional ECM molecules to achieve compaction of cells chains. Alternatively, integrins may cooperate with other secreted signaling molecules and cell surface receptors to control chain formation. Intriguingly, EphB and ErbB receptor tyrosine kinase control not only chain migration (Conover et al., 2000; Anton et al., 2004; Ghashghaei et al., 2006) but also the function of $\beta 1$ integrins in cell adhesion and migration (Adelsman et al., 1999; Huynh-Do et al., 1999; Davy and Robbins, 2000; Miao et al., 2000; Colognato et 
al., 2002). Therefore, the cooperative activation of integrins by laminin and receptor tyrosine kinases by their ephrin and neuregulin ligands may control the overall behavior of cells in chains. As one possibility, cooperative signaling by tyrosine kinases and integrins may be required to activate cellular signal transduction pathways that control the assembly of the actin cytoskeleton as described in other cell types (Schwartz and Ginsberg, 2002). In addition, integrins in epithelial cells control the activity of cadherins (Arregui et al., 2000; Yano et al., 2004), which may act downstream of integrins in the compaction of neuroblasts in cell chains. Likewise, defects in the formation of cell chains have been observed in mice deficient in the secreted chemorepellents slit1 and slit2 (Hu, 1999; Wu et al., 1999; Nguyen-Ba-Charvet et al., 2004), suggesting that integrins, laminins, and slit molecules may act in a common molecular pathway. We can at present only speculate how slits, integrins, and laminins cooperate to affect chain migration. An intriguing possibility is that laminins may bind slit molecules and help to establish a slit gradient. Alternatively, integrins may recruit laminin/slit complexes to the surface of neuroblasts to concentrate the slit ligand and facilitate the activation of slit receptors within cells. We are currently performing systematic perturbations of various molecular pathways to define the signals that cooperate with $\beta 1$ integrins in the formation and movement of cell chains.

Surprisingly, although Wichterle et al. (1997) have shown that cell migration is observed in Matrigel (which contains laminin and collagen) but not on polylysine or in collagen gels, Mason et al. (2001) have reported that chain migration occurs on polylysine even in the absence of Matrigel. These findings suggest that laminin may not be essential for chain migration. However, under the culture conditions used by Mason and colleagues (but not by Wichterle et al.), glial fibers emanated from the explants and neurons appeared to migrate along these fibers. Therefore, molecules secreted from the glial cells and including laminin may provide the necessary environment for chain migration under the culture conditions used by Mason and colleagues.

$\boldsymbol{\beta} 1$ integrins, laminin, and glial tubes Although our in vitro assays suggest that $\beta 1$ integrins control interactions between neuroblasts, our in vivo data suggest that integrins affect the RMS in different ways as well. Most prominently, the glial tubes
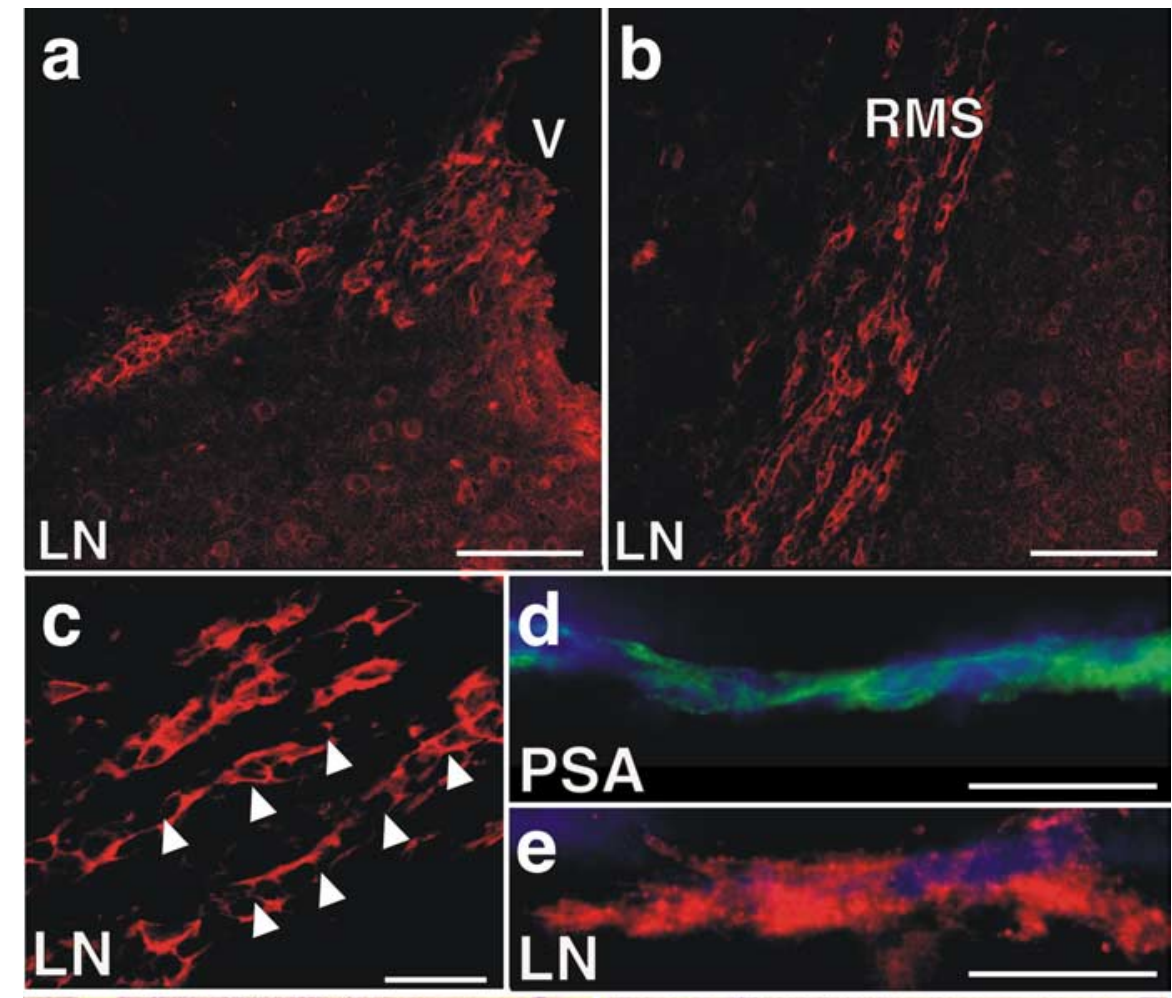

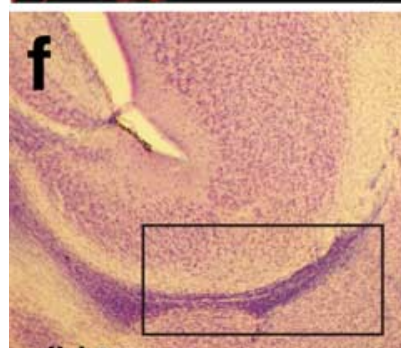

wild-type
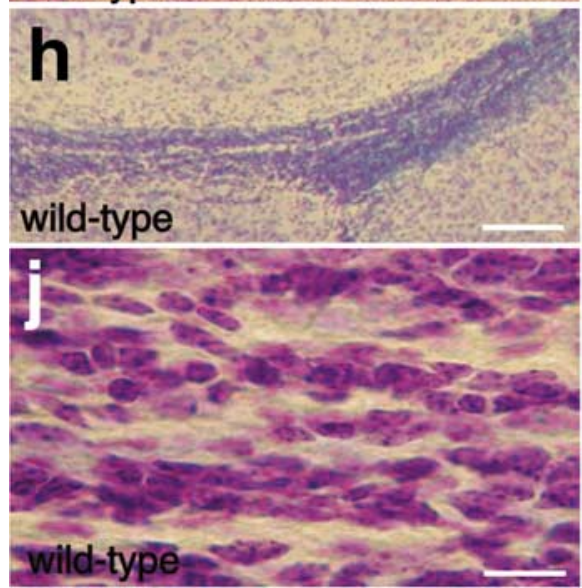

LNa2/a4-mutant

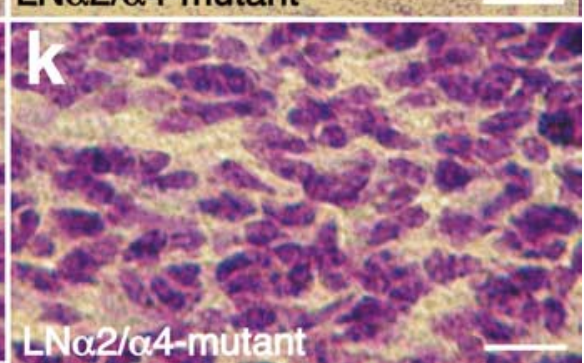

Figure 10. Laminin is required for chain migration. $\boldsymbol{a}-\boldsymbol{e}$, Sagittal sections through the RMS close to the ventricle $(\boldsymbol{a})$ and close to the $\mathrm{OB}(\boldsymbol{b})$ were stained with antibodies that recognize laminin $\alpha 1$ and $\alpha 2$. The two laminin subunits were highly expressed in the RMS and concentrated around cells. c shows a higher-magnification view of neuroblasts in cell chains. $\boldsymbol{d}$ and $\boldsymbol{e}$ are of the same chain stained with DAPI (blue) and antibodies to PSA (green) or to laminin $\alpha 1 / \alpha 2$ (red). Note that laminin $\alpha 1 / \alpha 2$ was concentrated at the surface of the neuroblasts within cell chains (arrowheads in $\boldsymbol{c}$ ). $\boldsymbol{f}$ - $\boldsymbol{k}$, Sagittal sections from 4-week-old wild-type mice and laminin $\alpha 2 / \alpha 4$ double-mutant mice were stained with Nissl. Images in $\boldsymbol{h}$ and $\boldsymbol{i}$ are higher-magnification views of the areas boxed in $\boldsymbol{f}$ and $\boldsymbol{g}$. Note that the RMS is less compact in the mutants. $\boldsymbol{j}, \boldsymbol{k}$, At high magnification, neuroblasts in cell chains that were aligned along the rostrocaudal axis of the RMS could be detected in wild-type mice but not in the mutants. Scale bars: $\boldsymbol{a}, \boldsymbol{b}, 150$ $\mu \mathrm{m} ; \boldsymbol{c}, 60 \mu \mathrm{m} ; \boldsymbol{d}, \boldsymbol{e}, 46 \mu \mathrm{m} ; \boldsymbol{f}, \boldsymbol{g}, 255 \mu \mathrm{m} ; \boldsymbol{h}, \boldsymbol{i}, 108 \mu \mathrm{m} ; \boldsymbol{j}, \boldsymbol{k}, 50 \mu \mathrm{m}$. 

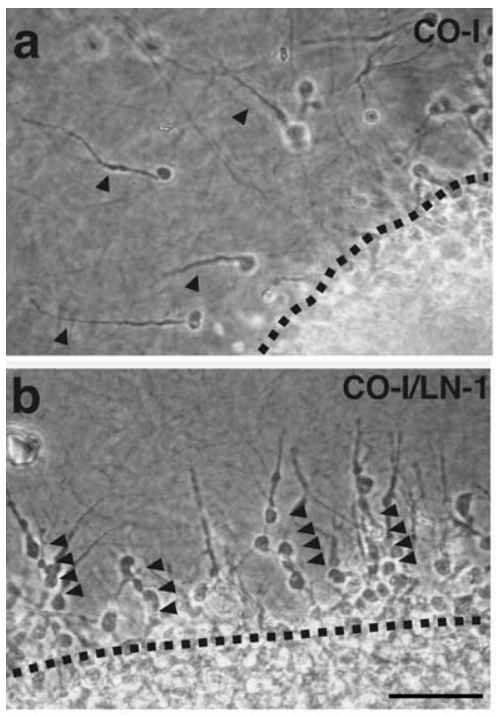

C
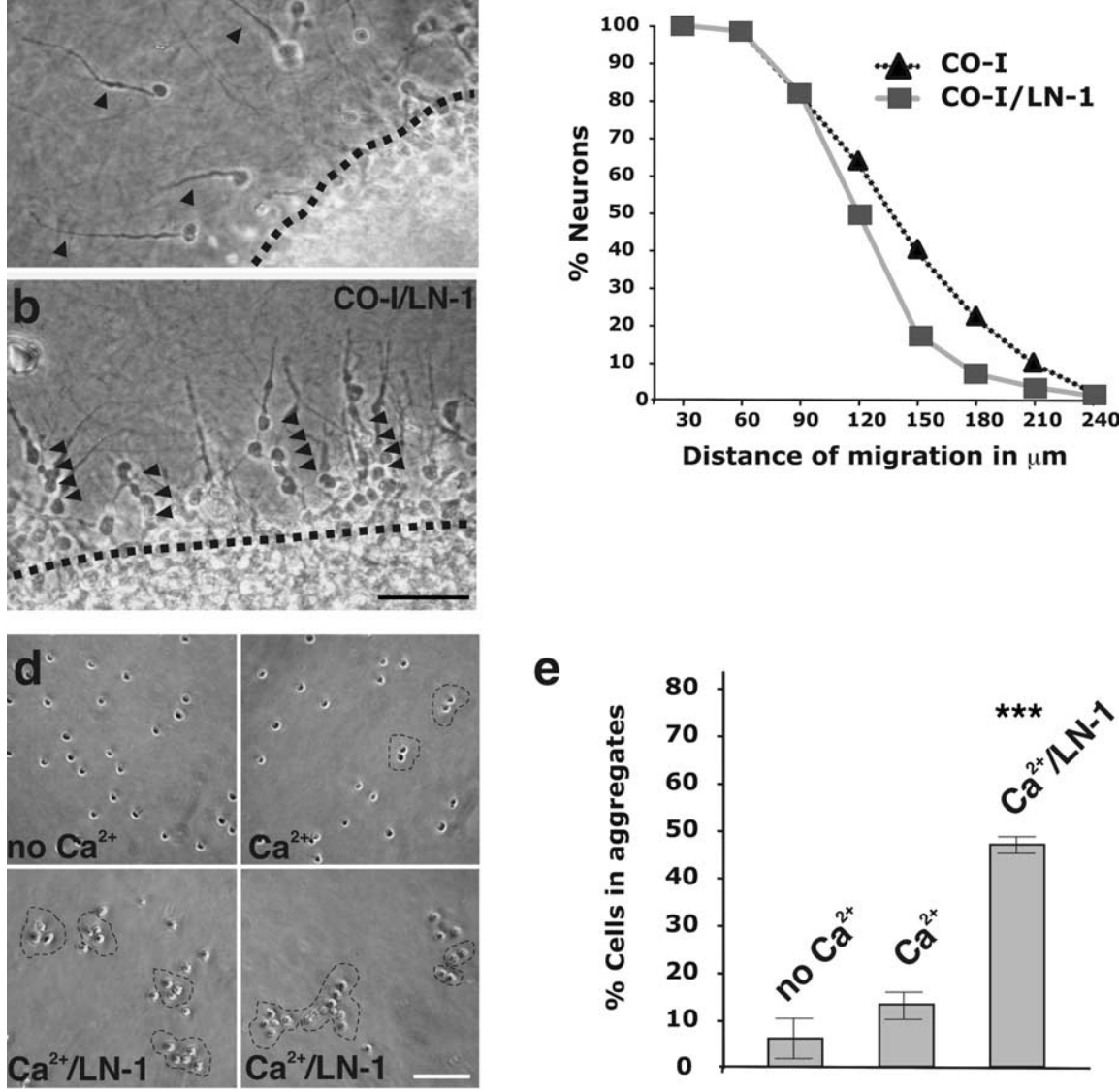

e

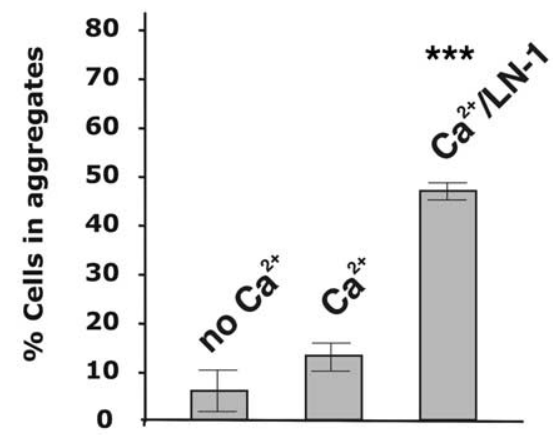

Figure 11. Laminin promotes chain formation and neuroblast aggregation in vitro. $\boldsymbol{a}, \boldsymbol{b}$, SVZ explants from wild-type mice were cultured in collagen gels or in mixed collagen (CO)/laminin-1 (LN) gels. Note that, although cells in collagen gels migrated at single cells, they were assembled into chains (arrowheads) in mixed collagen/laminin-1 gels. c, Cumulative frequency plot of the distance traveled by cell revealed that cells in chains migrated slightly less far than single cells, suggesting that overall migration speed was reduced when cells were assembled into chains. The values represent pooled data from three independent experiments. $\boldsymbol{d}$, FACS-sorted PSA-NCAM-positive cells were incubated for $2 \mathrm{~h}$ in buffer with or without $\mathrm{Ca}^{2+}$ and with or without laminin-1. Cell aggregation was only observed in the presence of $\mathrm{Ca}^{2+}$ and laminin-1. $\boldsymbol{e}$, Quantification of cell aggregation in three independent experiments. The mean and SE is shown; ${ }^{* * *} p<0.01$. Scale bars: $\boldsymbol{a}, \boldsymbol{b}, 100 \mu \mathrm{m} ; \boldsymbol{d}, 90 \mu \mathrm{m}$.

are disrupted in Itgb1-CNSko mice. These defects could be a secondary consequence of perturbations in interactions between neurons or could affect glial cells more directly. Although the glial tubes are not essential for neuronal chain migration in the in vitro Matrigel assay (Wichterle et al., 1997), we observed an increasing number of integrin $\beta 1$-deficient neuroblasts leaving the RMS prematurely on route to the OB. The glial tubes may provide a physical boundary lining the migratory pass of neuroblasts, but it may also have a more active role to control migration. An interesting hypothesis would be that the glial tubes generate a corridor for migration by secreting signaling molecules, affecting the formation of chains and controlling migrational speed. This model is consistent with the findings reported here. The data also suggest that the reduced size of the OB in Itgb1-CNSko mice is a consequence of perturbations in the formation of both cell chains and the glial tubes, affecting migrational speed and allowing some cells to leave the RMS prematurely. Overall, this leads to a net loss of the number of cells that reach the $\mathrm{OB}$ and therefore to a reduction in the size of the OB.

\section{$\beta 1$ integrins and cell migration in the CNS}

Previous studies have addressed the function of $\beta 1$ integrins in neuronal precursors. These studies that were mainly performed under well defined in vitro conditions have provided compelling evidence that integrin signaling controls the adhesion, maintenance, and migration of neuronal precursors (Campos et al., 2004; Tate et al., 2004; Andressen et al., 2005). However, the function of $\beta 1$ integrins in neuronal precursors and in differentiating neurons in the more complex in vivo environment is less well understood. Studies over the past decades have demonstrated that neuronal precursors and differentiating neurons in the CNS migrate by different modes, including radial migration along glial fibers, tangential migration along neuronal processes, and migration in cell chains (Alvarez-Buylla and GarciaVerdugo, 2002; Hatten, 2002; Marin and Rubenstein, 2003; Kriegstein and Noctor, 2004). $\beta 1$ integrins were thought to control cell motility in several of these modes of migration (Clegg et al., 2003), but our findings suggest that $\beta 1$ integrins have a much more specific role than previously appreciated. Our previously published data (Graus-Porta et al., 2001; Blaess et al., 2004) provide strong evidence that many of the migratory events that are important for the development of the cerebral and cerebellar cortex progress normally in the absence of $\beta 1$ integrins. Similarly, although studies with function blocking antibodies have suggested that $\beta 1$ integrins control cell motility of neuroblasts in the RMS, for example by controlling leading process extension (Murase and Horwitz, 2002; Emsley and Hagg, 2003), our data now show that $\beta 1$-deficient neuroblasts in the RMS still elaborate extensive leading processes and are able to migrate directionally toward the OB. However, the cells migrate with reduced speed, suggesting that integrins control some aspects of migration. In fact, directional cell motility is a complex process and likely depends on the cooperative action of several cell surface receptors. Likewise, once the cells reach the $\mathrm{OB}$, chains are disassembled and cell switch to a radial mode of migration. The secreted signaling molecules reelin, tenascin $\mathrm{R}$, and prokineticin-2 induce detachment of neuroblasts from cell chains (Hack et al., 2002; Saghatelyan et al., 2004; Ng et al., 2005), but the function of integrins in this process is unclear. We observed radially migrating cells in Itgb1-CNSko mice, but, because cell migration within the RMS already was perturbed, we could not quantify whether integrins are required for reelin, tenascin $\mathrm{R}$, or prokineticin-2 signaling. Additional experiments will be necessary to address this possibility.

\section{References}

Adelsman MA, McCarthy JB, Shimizu Y (1999) Stimulation of beta1integrin function by epidermal growth factor and heregulin-beta has distinct requirements for erbB2 but a similar dependence on phosphoinositide 3-OH kinase. Mol Biol Cell 10:2861-2878.

Alvarez-Buylla A, Garcia-Verdugo JM (2002) Neurogenesis in adult subventricular zone. J Neurosci 22:629-634. 
Alvarez-Buylla A, Lim DA (2004) For the long run: maintaining germinal niches in the adult brain. Neuron 41:683-686.

Andressen C, Adrian S, Fassler R, Arnhold S, Addicks K (2005) The contribution of betal integrins to neuronal migration and differentiation depends on extracellular matrix molecules. Eur J Cell Biol 84:973-982.

Anton ES, Ghashghaei HT, Weber JL, McCann C, Fischer TM, Cheung ID, Gassmann M, Messing A, Klein R, Schwab MH, Lloyd KC, Lai C (2004) Receptor tyrosine kinase ErbB4 modulates neuroblast migration and placement in the adult forebrain. Nat Neurosci 7:1319-1328.

Arregui C, Pathre P, Lilien J, Balsamo J (2000) The nonreceptor tyrosine kinase fer mediates cross-talk between $\mathrm{N}$-cadherin and betal-integrins. J Cell Biol 149:1263-1274.

Belvindrah R, Rougon G, Chazal G (2002) Increased neurogenesis in adult mCD24-deficient mice. J Neurosci 22:3594-3607.

Blaess S, Graus-Porta D, Belvindrah R, Radakovits R, Pons S, LittlewoodEvans A, Senften M, Guo H, Li Y, Miner JH, Reichardt LF, Muller U (2004) Betal-integrins are critical for cerebellar granule cell precursor proliferation. J Neurosci 24:3402-3412.

Bokel C, Brown NH (2002) Integrins in development: moving on, responding to, and sticking to the extracellular matrix. Dev Cell 3:311-321.

Campos LS, Leone DP, Relvas JB, Brakebusch C, Fassler R, Suter U, ffrenchConstant C (2004) Betal integrins activate a MAPK signalling pathway in neural stem cells that contributes to their maintenance. Development 131:3433-3444.

Chazal G, Durbec P, Jankovski A, Rougon G, Cremer H (2000) Consequences of neural cell adhesion molecule deficiency on cell migration in the rostral migratory stream of the mouse. J Neurosci 20:1446-1457.

Clegg DO, Wingerd KL, Hikita ST, Tolhurst EC (2003) Integrins in the development, function and dysfunction of the nervous system. Front Biosci 8:d723-d750.

Colognato H, Baron W, Avellana-Adalid V, Relvas JB, Baron-Van Evercooren A, Georges-Labouesse E, ffrench-Constant C (2002) CNS integrins switch growth factor signalling to promote target-dependent survival. Nat Cell Biol 4:833-841.

Conover JC, Doetsch F, Garcia-Verdugo JM, Gale NW, Yancopoulos GD, Alvarez-Buylla A (2000) Disruption of Eph/ephrin signaling affects migration and proliferation in the adult subventricular zone. Nat Neurosci 3:1091-1097.

Cremer H, Lange R, Christoph A, Plomann M, Vopper G, Roes J, Brown R, Baldwin S, Kraemer P, Scheff S, Barthels D, Rajewsky K, Wille W (1994) Inactivation of the N-CAM gene in mice results in size reduction of the olfactory bulb and deficits in spatial learning. Nature 367:455-459.

Davy A, Robbins SM (2000) Ephrin-A5 modulates cell adhesion and morphology in an integrin-dependent manner. EMBO J 19:5396-5405.

Doetsch F, Garcia-Verdugo JM, Alvarez-Buylla A (1997) Cellular composition and three-dimensional organization of the subventricular germinal zone in the adult mammalian brain. J Neurosci 17:5046-5061.

Emsley JG, Hagg T (2003) alpha6betal integrin directs migration of neuronal precursors in adult mouse forebrain. Exp Neurol 183:273-285.

Ghashghaei HT, Weber J, Pevny L, Schmid R, Schwab MH, Lloyd KC, Eisenstat DD, Lai C, Anton ES (2006) The role of neuregulin-ErbB4 interactions on the proliferation and organization of cells in the subventricular zone. Proc Natl Acad Sci USA 103:1930-1935.

Graus-Porta D, Blaess S, Senften M, Littlewood-Evans A, Damsky C, Huang Z, Orban P, Klein R, Schittny JC, Muller U (2001) Beta1-class integrins regulate the development of laminae and folia in the cerebral and cerebellar cortex. Neuron 31:367-379.

Hack I, Bancila M, Loulier K, Carroll P, Cremer H (2002) Reelin is a detachment signal in tangential chain-migration during postnatal neurogenesis. Nat Neurosci 5:939-945.

Hatten ME (2002) New directions in neuronal migration. Science 297:1660-1663.

Hu H (1999) Chemorepulsion of neuronal migration by Slit2 in the developing mammalian forebrain. Neuron 23:703-711.

Hu H, Rutishauser U (1996) A septum-derived chemorepulsive factor for migrating olfactory interneuron precursors. Neuron 16:933-940.

Hu H, Tomasiewicz H, Magnuson T, Rutishauser U (1996) The role of polysialic acid in migration of olfactory bulb interneuron precursors in the subventricular zone. Neuron 16:735-743.

Huang X, Griffiths M, Wu J, Farese JR RV, Sheppard D (2000) Normal development, wound healing, and adenovirus susceptibility in beta5deficient mice. Mol Cell Biol 20:755-759.
Huynh-Do U, Stein E, Lane AA, Liu H, Cerretti DP, Daniel TO (1999) Surface densities of ephrin-B1 determine EphB1-coupled activation of cell attachment through alphavbeta3 and alpha5betal integrins. EMBO J 18:2165-2173.

Hynes RO (2002) Integrins: bidirectional, allosteric signaling machines. Cell 110:673-687.

Kempermann G, Wiskott L, Gage FH (2004) Functional significance of adult neurogenesis. Curr Opin Neurobiol 14:186-191.

Kriegstein AR, Noctor SC (2004) Patterns of neuronal migration in the embryonic cortex. Trends Neurosci 27:392-399.

Kuo CT, Mirzadeh Z, Soriano-Navarro M, Rasin M, Wang D, Shen J, Sestan N, Garcia-Verdugo J, Alvarez-Buylla A, Jan LY, Jan YN (2006) Postnatal deletion of Numb/Numblike reveals repair and remodeling capacity in the subventricular neurogenic niche. Cell 127:1253-1264.

Lendahl U, Zimmerman LB, McKay RD (1990) CNS stem cells express a new class of intermediate filament protein. Cell 60:585-595.

Lledo PM, Alonso M, Grubb MS (2006) Adult neurogenesis and functional plasticity in neuronal circuits. Nat Rev Neurosci 7:179-193.

Lois C, Alvarez-Buylla A (1994) Long-distance neuronal migration in the adult mammalian brain. Science 264:1145-1148.

Lois C, Garcia-Verdugo JM, Alvarez-Buylla A (1996) Chain migration of neuronal precursors. Science 271:978-981.

Luskin MB (1993) Restricted proliferation and migration of postnatally generated neurons derived from the forebrain subventricular zone. Neuron 11:173-189.

Mao X, Fujiwara Y, Orkin SH (1999) Improved reporter strain for monitoring Cre recombinase-mediated DNA excisions in mice. Proc Natl Acad Sci USA 96:5037-5042.

Marin O, Rubenstein JL (2003) Cell migration in the forebrain. Annu Rev Neurosci 26:441-483.

Mason HA, Ito S, Corfas G (2001) Extracellular signals that regulate the tangential migration of olfactory bulb neuronal precursors: inducers, inhibitors, and repellents. J Neurosci 21:7654-7663.

Merkle FT, Tramontin AD, Garcia-Verdugo JM, Alvarez-Buylla A (2004) Radial glia give rise to adult neural stem cells in the subventricular zone. Proc Natl Acad Sci USA 101:17528-17532.

Miao H, Burnett E, Kinch M, Simon E, Wang B (2000) Activation of EphA2 kinase suppresses integrin function and causes focal-adhesion-kinase dephosphorylation. Nat Cell Biol 2:62-69.

Miner JH, Yurchenco PD (2004) Laminin functions in tissue morphogenesis. Annu Rev Cell Dev Biol 20:255-284.

Murase S, Horwitz AF (2002) Deleted in colorectal carcinoma and differentially expressed integrins mediate the directional migration of neural precursors in the rostral migratory stream. J Neurosci 22:3568-3579.

Ng KL, Li JD, Cheng MY, Leslie FM, Lee AG, Zhou QY (2005) Dependence of olfactory bulb neurogenesis on prokineticin 2 signaling. Science 308:1923-1927.

Nguyen-Ba-Charvet KT, Picard-Riera N, Tessier-Lavigne M, Baron-Van Evercooren A, Sotelo C, Chedotal A (2004) Multiple roles for slits in the control of cell migration in the rostral migratory stream. J Neurosci 24:1497-1506.

Ono K, Tomasiewicz H, Magnuson T, Rutishauser U (1994) N-CAM mutation inhibits tangential neuronal migration and is phenocopied by enzymatic removal of polysialic acid. Neuron 13:595-609.

Paratcha G, Ibanez CF, Ledda F (2006) GDNF is a chemoattractant factor for neuronal precursor cells in the rostral migratory stream. Mol Cell Neurosci 31:505-514.

Patton BL, Cunningham JM, Thyboll J, Kortesmaa J, Westerblad H, Edstrom L, Tryggvason K, Sanes JR (2001) Properly formed but improperly localized synaptic specializations in the absence of laminin alpha4. Nat Neurosci 4:597-604.

Saghatelyan A, de Chevigny A, Schachner M, Lledo PM (2004) Tenascin-R mediates activity-dependent recruitment of neuroblasts in the adult mouse forebrain. Nat Neurosci 7:347-356.

Sawamoto K, Wichterle H, Gonzalez-Perez O, Cholfin JA, Yamada M, Spassky N, Murcia NS, Garcia-Verdugo JM, Marin O, Rubenstein JL, Tessier-Lavigne M, Okano H, Alvarez-Buylla A (2006) New neurons follow the flow of cerebrospinal fluid in the adult brain. Science 311:629-632.

Scherer A, Krause A, Walker JR, Sutton SE, Seron D, Raulf F, Cook MP (2003) Optimized protocol for linear RNA amplification And applica- 
tion to gene expression profiling of human renal biopsies. Biotechniques 34:552-554.

Schwartz MA, Ginsberg MH (2002) Networks and crosstalk: integrin signalling spreads. Nat Cell Biol 4:E65-E68.

Su AI, Wiltshire T, Batalov S, Lapp H, Ching KA, Block D, Zhang J, Soden R, Hayakawa M, Kreiman G, Cooke MP, Walker JR, Hogenesch JB (2004) A gene atlas of the mouse and human protein-encoding transcriptomes. Proc Natl Acad Sci USA 101:6062-6067.

Sunada Y, Bernier SM, Kozak CA, Yamada Y, Campbell KP (1994) Deficiency of merosin in dystrophic dy mice and genetic linkage of laminin M chain gene to dy locus. J Biol Chem 269:13729-13732.

Tate MC, Garcia AJ, Keselowsky BG, Schumm MA, Archer DR, LaPlaca MC (2004) Specific betal integrins mediate adhesion, migration, and differentiation of neural progenitors derived from the embryonic striatum. Mol Cell Neurosci 27:22-31.

Teyssier C, Ma H, Emter R, Kralli A, Stallcup MR (2005) Activation of nuclear receptor coactivator PGC-1alpha by arginine methylation. Genes Dev 19:1466-1473.

Tomasiewicz H, Ono K, Yee D, Thompson C, Goridis C, Rutishauser U,
Magnuson T (1993) Genetic deletion of a neural cell adhesion molecule variant (N-CAM-180) produces distinct defects in the central nervous system. Neuron 11:1163-1174.

Tronche F, Kellendonk C, Kretz O, Gass P, Anlag K, Orban PC, Bock R, Klein R, Schutz G (1999) Disruption of the glucocorticoid receptor gene in the nervous system results in reduced anxiety. Nat Genet 23:99-103.

Wichterle H, Garcia-Verdugo JM, Alvarez-Buylla A (1997) Direct evidence for homotypic, glia-independent neuronal migration. Neuron 18:779-791.

Wu W, Wong K, Chen J, Jiang Z, Dupuis S, Wu JY, Rao Y (1999) Directional guidance of neuronal migration in the olfactory system by the protein Slit. Nature 400:331-336.

Xu H, Christmas P, Wu XR, Wewer UM, Engvall E (1994) Defective muscle basement membrane and lack of M-laminin in the dystrophic dy/dy mouse. Proc Natl Acad Sci USA 91:5572-5576.

Yano H, Mazaki Y, Kurokawa K, Hanks SK, Matsuda M, Sabe H (2004) Roles played by a subset of integrin signaling molecules in cadherin-based cell-cell adhesion. J Cell Biol 166:283-295. 